GEOTHERMAL ENERGY AT LONG BEACH NAVAL SHIPYARD

AND NAVAL STATION AND AT SEAL BEACH NAVAL WEAPONS STATION,

CALIFORNIA

by

Chris T. Higgins, Geologist

Rodger H. Chapman, Geophysicist

$\mathrm{DOE} / \mathrm{SE} / 11720--\mathrm{T}_{1} 3$

DE35 002994

\title{
California Department of Conservation
}

Division of Mines and Geology

OPEN FILE REPCIRT 84-32 SAC

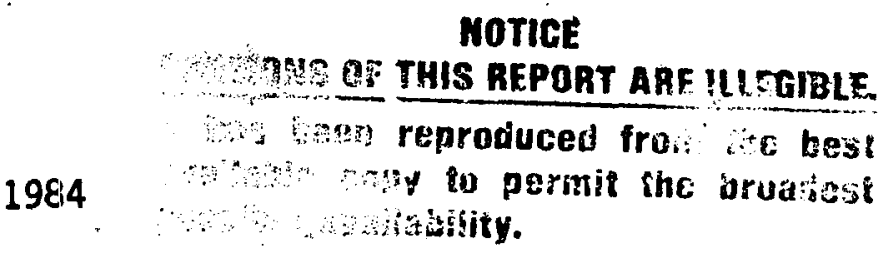

This work was performed under Con tract No. DE-ACO3-83SF11720. for the U.S. Department of Energy, San Francisco Operations Office, by the California Department of Conservation, Division of Mines and Geology.

It was part of a cooperative agreement between the Department of Energy's San Francisco Operations Office and the U.S. Naval Weapons Center, China Lake, California, for joint research and development of geothermal energy at military installations.

\section{DISCLAIMER}

This report was prepared as an account of work sponsored by an agency of the United States Government. Neither the United States Government nor any agency thereof, nor any of their employees, makes any warranty, express or implied, or assumes any legal liability or responsibility for the accuracy, completeness, or usefulness of any information, apparatus, product, or process disclosed, or represents that its use wculd not infringe privately owned rights. Reference herein to any specific commercial product, process, or service by trade name, trademark, manufacturer, or otherwise does not necessarily constitute or imply its endorsement, recommendation, or favoring by the United States Government or any agency thereof. The views and opinions of authors expressed herein do not necessarily state or reflect those of the United States Government or any agency thereof. 


\section{DISCLAIMER}

This report was prepared as an account of work sponsored by an agency of the United States Government. Neither the United States Government nor any agency Thereof, nor any of their employees, makes any warranty, express or implied, or assumes any legal liability or responsibility for the accuracy, completeness, or usefulness of any information, apparatus, product, or process disclosed, or represents that its use would not infringe privately owned rights. Reference herein to any specific commercial product, process, or service by trade name, trademark, manufacturer, or otherwise does not necessarily constitute or imply its endorsement, recommendation, or favoring by the United States Government or any agency thereof. The views and opinions of authors expressed herein do not necessarily state or reflect those of the United States Government or any agency thereof. 


\section{DISCLAIMER}

Portions of this document may be illegible in electronic image products. Images are produced from the best available original document. 
EXECUTIVE SUMMARY............................................ 1

INTRODUCTION................................................... 4

PURPOSE AND LOCATION OF STUDY................................. 4

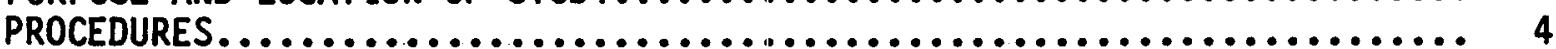

PREVIOUS STUDY..............,

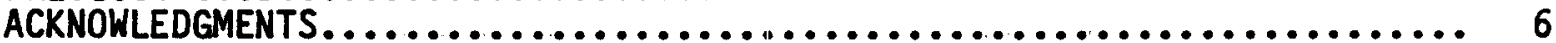

REGIONAL GEOLOGIC SETTING.................................... 7

STRATIGRAPHY AND STRUCTURE.................................. 7

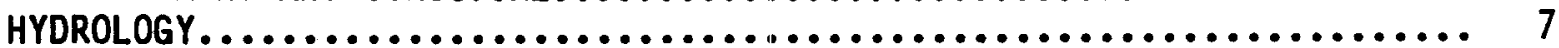

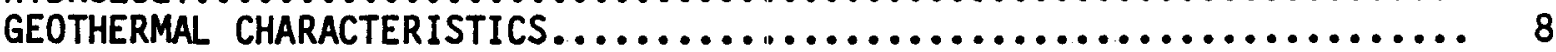

LONG BEACH NAVAL SHIPYARD AND NAVAL STATION..................... 10

PHYSICAL SETTING.......................................... 10

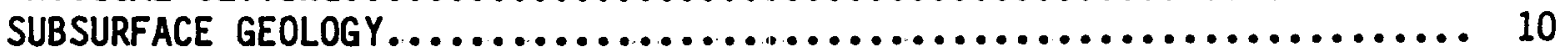

Stratigraphy.............................................. 10

structure.............................................. 10

Geothermal Gradient...................................... 14

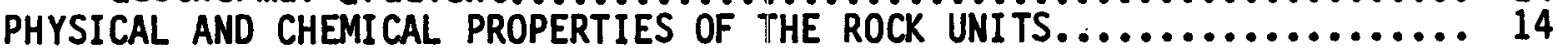

Shall ow (Fresh-Water) Sediments............................. 14

Deep (Sal ine-Water) Sedimentary Rocks......................... 16

Basement................................................ 16

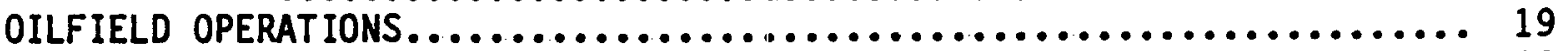

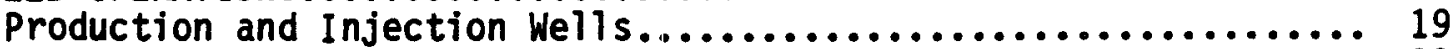

Collection and Disposal of Fluids............................., 22

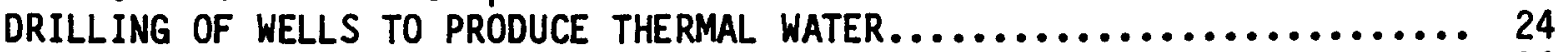

Temperature............................................... 24

Permeabil ity............................................... 24

Recharge............................................. 25

Effects on Production of $0 i 1 \ldots \ldots \ldots \ldots \ldots \ldots \ldots \ldots \ldots \ldots \ldots \ldots \ldots, 25$

Drilling and Operation of Welis

EXTRACTION OF HEAT FROM OILFIELD OPERATIONS.................., 26

Wells Versus Central Facilities as Sources of Heat............. 26

Effects of Extraction of Heat on 0ilfield Operations. ......... 27

Transfer of Heat......................................... 27

Longevity of 0ilfield Operations......................... 28

SEAL BEACH NAVAL WEAPONS STATION........................... 29

PHYSICAL SETTING......................................... 29

SUBSURFACE GEOLOGY........................................ 29

Stratigraphy............................................ 29

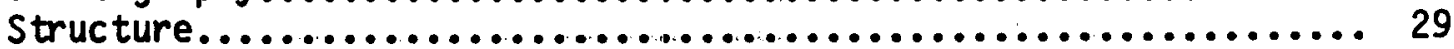

Geophysical Investigations............................... 33

Gravity Data and its Interpretation....................... 34

Geothermal Gradient................................. 35 
PHYSICAL AND CHEMICAL PROPERTIES OF THE ROCK UNITS................ 38

Shall ow (Fresh-Water) Sediments.............................. 38

Deep (Sal ine-Water) Sedimentary Rocks......................... 39

Basement................................................... 39

OILFIELD OPERATIONS.......................................... 39

Production and Injection/Disposal Wei is ............................. 43

Collection and Disposal of Fluids............................... 46

DRILLING OF WELLS TO PRODUCE THERMAL WATER..., $\ldots \ldots \ldots \ldots \ldots \ldots \ldots \ldots, 46$

Temperature................................................. 46

Permeability............................................ 48

Recharge............................................. 48

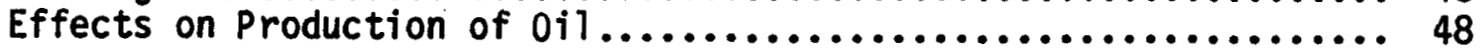

Drilling and Operation of Wells.............................. 49

EXTRACTION OF HEAT FROM OILFIELD OPERATIONS $. \ldots \ldots \ldots \ldots \ldots \ldots \ldots \ldots \ldots ., 49$

Wells Versus Central Facilities as Sources of Heat................ 49

Effects of Extraction of Heat on 0ilfield Operations............. 50

Transfer of Heat........................................... 50

Longevity of $0 i l f i e l d$ Operations $\ldots \ldots \ldots \ldots \ldots \ldots \ldots \ldots \ldots \ldots \ldots, 50$

CONCLUSIONS AND RECOMMENDATIONS............................. 51

LONG BEACH NAVAL SHIPYARD AND NAYAL STATION.................... 51

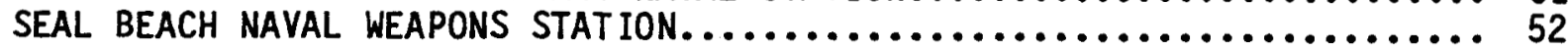

SELECTED REFERENCES...................................... 55

APPENDIX A - Gravity Survey at Seal Beach Naval Weapons Station.......... 58

LIST OF FIGURES

No.

Page

1 Location of naval bases and prominent geologic structures in

the Los Angeles basin................................. 5

2 Stratigraphy beneath the Long Beach naval base.................. 11

3 Depth to basement beneath the Long Beach naval base................ 12

4 Generalized structure on top of the Ranger zone at

Wilmington $0 i 1$ Field..................................... 13

5 Curve of geothermal gradient beneath the Long Beach

naval base.......................................... 15

6 Locations of oilfield leases and operations on and

adjacent to the Long Beach naval base....................... 20

7 Generalized geology at the Seal Beach Naval Weapons Station.......... 30

8 Stratigraphy beneath the Seal Beach Naval Weapons Station........... 31

9 Depth to basement beneath the Seal Beach Naval

Weapons Station...................................... 32

10 Residual gravity profile along $k i t t$ Avenue on the Seal Beach

Naval Weapons Station..................................... 36

11 Curve of estimated geothermal gradient beneath the southwest part of the Seal Beach Naval Weapons Station................... 37

12 Locations of oilfield leases and operations on and adjacent

to the Seal Beach Naval Weapons Station........................ 
No.

1 Physical and chemical properties of oil-producing zones in the Wilmington 0il Field adjacent to the Long Beach naval base......... 17

2 Detailed chemistry of water produced from selected oil-producing zones in the Wilmington 0 il Field.................. 18

3 Temperatures and volumes of fluids produced from selected $0 i 1$ wells on the LBOD "W" lease............................... 21

4 Temperatures and volumes of water processed at centralized oilfield facilities on or adjacent to the Long Beach naval

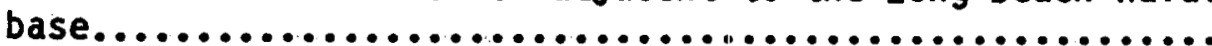

5 Physical and chemical properties of oil-producing zones in the Seal Beach 0il Field on and adjacent to the seal Beach Naval Weapons Station............................... 40 Detailed chemistry of water produced from selected oil-producing zones in the Seal Beach 0il Field................. 41

7 Temperatures and volumes of fluids produced from oil wells on the RCU Operator "Alamitos" lease........................... 44

8 Temperatures and volumes of fluids produced from selected oil wells on the Hellman Estate leases........................ 45

9 Temperatures and volumes of fiuids processed at centralized oilfield facilities on or adjacent to the Seal Beach Naval Weapons Station.

\section{LIST OF PLATES}

No.

1 Map of the Long Beach Naval Shipyard and Naval Station.............Pocket

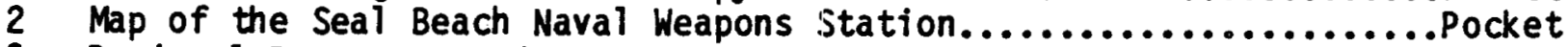

3 Regional Bouguer gravity map of the area including the

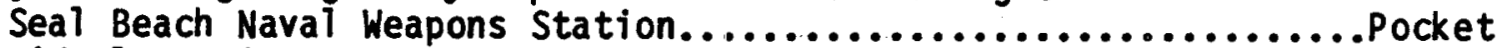

4 Residual gravity map of the area including the

Seal Beach Naval Weapons Station.......................... Pocket 


\section{EXECUTIVE SUMMARY}

The purpose of this project was to determine and evaluate sources of geothermal energy at two military bases in southern California, the Long Beach Naval Shipyard and Naval Station and the Seal Beach Naval Weapons Station. One part of the project focused on the noltural geothermal characteristics beneath the naval bases. Another part focused on the geothermal energy produced by oilfield operations on and acljacent to each base. Results of the study are presented here for the U.S. Department of the Navy to use in its program to reduce its reliance on petroleum by the development of different sources of energy. The study was accomplished under a cooperative agreement between the U.S. Department of Energy's San Francisco Operations Office and

the Department of the Navy's Naval Weaporis Center, China Lake, California, for joint research and development of geothermal energy at military installations.

\section{PROCEDURES}

The project required research of various reports and data, both published and unpublished, particularly those of the California Department of Conservation, Division of $0 i 1$ and Gas and of $0 i 1$ companies with leases on or adjacent to the naval bases. Important field investigations included the measurement of well-head temperatures of fluids produced from selected oil wells at each naval base and a detailed gravity survey of the Seal Beach naval base and vicinity. The well-head temperatures were needed to evaluate individual wells as sources of geothermal energy, while the gravity survey attempted to discover subsurface geologic structures that might contain geothermal fluids of temperatures higher than those predicted by the regional geothermal conditions.

\section{FINDINGS AND CONCLUSIONS}

Each naval base is underlain by many thousands of feet of sedimentary rocks heated by thermal conduction from deeper crystalline rock; the anomalous rise of high-temperature water from great: depths by thermal convection along open, near-vertical fractures in the sediments is probably of minor extent. Fur thermore, there are no known bodies of magma beneath either naval base. The rate of increase of temperature with depth (geothermal gradient) beneath the Long Beach naval base is almost twice the earth's average rate, while below the Seal Beach naval base, the rate of increase is a little above average. A temperature of $212^{\circ} \mathrm{F}$ (boiling point of water at sea level) is expected at depths of about 5,300 feet at: the Long Beach naval base and about 6,700 feet at the Seal Beach naval base. At both bases, the sedimentary rocks below a depth of a few thousand feet contain saline waters of very poor chemical quality. The rate of movement of water through the sedimentary rocks tends to decrease with depth because of the weight of compaction from overlying layers; therefore, the hottest rock formations are generaliy the least permeable. Furthermore, as depth increases, it becomes less likely that the sedimentary rocks will be naturally replenished with water if the existing water in them were to be removed by geothermal wells.

To attain the minimum temperatures (alpproximately $230^{\circ} \mathrm{F}$ ) necessary to produce small amounts of electricity fronl a generator placed on a geothermal well, the well would probably have to be drilled to at least 6,000 feet at the Long Beach naval base and at least 7,500 feet at the Seal Beach naval base. For generation of large quantities of electricity by a power plant, temperatures of at least $300^{\circ} \mathrm{F}$ are needed, which would require driliting to at 
least 7,500 feet at Long Beach and about 10,000 feet at Seal Beach. At these depths, however, the sedimentary rocks are ijkely to be insufficiently permeable to provide adequate fluid to the wells for the generation of economic amounts of electricity. Regarding sufficient temperatures and permeabilities for nonelectrical uses of geothermal energy at either base, these can be attained at shallower depths than those mentioned, al though the economic value of this heat is less than that of heat capable of production of electricity. At the shallowest depths, the sediments will be most permeable, yet the temperatures will be insufficient even for most nonelectrical uses. At the Seal Beach naval base, the gravity survey did not reveal any unknown structures that might be potential sites for drilling to produce geothermal fluids for electrical or nonelectrical uses.

A few centralized fluid-processing facilities, associated with oilfield operations at or near both naval bases, process waters that contain low-grade heat $\left(<125^{\circ} \mathrm{F}\right)$ that might be applied to nonelectrical uses of energy at each base. At Long Beach, the most promising facility is Champl in Petroleum Company's "Island" injection plant, which is about 200 meters north of the base and processes approximately 5,200 gallons/minute of $112^{\circ} \mathrm{F}$-water. A less-promising facility is Long Beach 0il Development Company's "Pier E" injection plant, which is on the naval base; it contains about five times less thermal energy than the "Island" plant. Because retention of heat in these facilities aids the recovery of oil, neither facility's operator has been inclined to support the extraction of heat from the facilities for outside uses, although this attitude may change for technological or economic reasons. At Seal Beach, the central facility at RCU Operator's "Alamitos" lease is a candidate for extraction of heat for use on the naval base, al though its processed volume of about 80 gallons/minute of $122^{\circ} \mathrm{F}$-fluid (60 gallons/minute of water) may be too small for economic use. The operator is interested, however, in such a project as there is no need to retain heat in the water separated from the oil.

At the Long Beach naval base, well-head temperatures on $0 i 1$ wells probably range between about $86^{\circ}$, and $161^{\circ} \mathrm{F}$, with rates of production generally less than 20 gallons/minute. At the Seal Beach naval base, well-head temperatures range from about $81^{\circ}$ to $163^{\circ} \mathrm{F}$, with rates of production generally less than 10 galions/minute. Although the temperatures are high on some wells, the individual rates of production from most if not all wells are probably too small to warrant extraction of heat at well-heads for uses on either base.

\section{RECOMMENDATIONS}

At this time, drilling of geothermal wells on either naval base is not recommended for several reasons. Most importantly, the wells would have to be drilled to and operated at uneconomical depths compared to the economic value of the heat that would be produced from them. An alternative to drilling new wells, however, may be the conversion of a few oil wells to geothermal wells. This idea was not studied here, but may be worthy of a brief investigation to determine if it would be economical.

A brief study of extraction of heat at the "Island" and "Pier E" facilities for use on the Long Beach naval base and at the "Alamitos" facility for use on the Seal Beach naval base is recommended. The first step in this study is to determine the owners of the legal rights to the heat in the facilities. The next step is to ascertain if these owners and the operators 
of the facilities (if different from the owners of the legal rights) are willing to cooperate in a possible project to extract heat for use on the bases. Finally, if these parties are agreeable, then an engineering study of each facility and each naval base's consumption of energy should determine if the project will be economical.

In the future, when the oil fields near depletion of their reserves, it is recommended that conversion of the oilfield operations to the production of thermal water for uses on the bases be considered. 
The main purpose of this study was to determine the characteristics of geothermal energy beneath two military bases in southern California operated by the U.S. Department of the Navy. One base, the Long Beach Naval Shipyard and Naval Station is in Los Angeles County, while the other, the Seal Beach Naval Weapons Station, is in Orange County, about 10 kilometers away (Figure 1). Parts of both naval bases are situated within oil fields, the former in Wilmington 0il Field, the latter in Seal Beach 0il Field. An important part of the study involved the oilfield operations on and immediately adjacent to the bases; these were also investigated as potential sources of geothermal energy.

The Department of the Navy determined that the geothermal characteristics of each base should be studied as part of the Navy's program to reduce its dependence on petroleum by the development of different sources of energy. The Department of the Navy and the U.S. Department of Energy agreed to the investigation under a cooperative agreement between the Naval Weapons Center, China Lake, California, and the Department of Energy's San Francisco Operations office for joint research and development of geothermal energy at military installations. The Department of Energy provided funds for the study under contract number DE-ACO3-83SF11720, which was in effect from September 1983 through May 1984.

\section{PROCEDURES}

Various reports and data, both published and unpublished, were researched for this project. Among the most important sources of information were the California Department of Conservation, Division of $0 i 1$ and Gas and the various oil companies with leases and operations on or adjacent to each naval base.

Important field investigations by the Division of Mines and Geology included the measurement of well-head temperatures of fluids produced from selected oil wells at each naval base and a detailed gravity survey of the Seal Beach Naval Weapons Station and vicinity. The former aided our evaluation of individual oil wells as sources of geothermal energy, while the latter attempted to improve our knowledge of geologic structures that might contain high-temperature geothermal fluids.

PREVIOUS STUDY

Previous studies of geothermal resources in the coastal area near Los Angeles are few and mainly of a reconnaissance nature. Reports by Robinson (1974), Keene (1974), Sal tzman (1978), and Higgins (1981) discussed the geothermal resources of Los Angeles County as a whole. The last report focused on oilfield operations in the County as sources of geothermal energy. Some data compiled in the present report were derived from that study. 


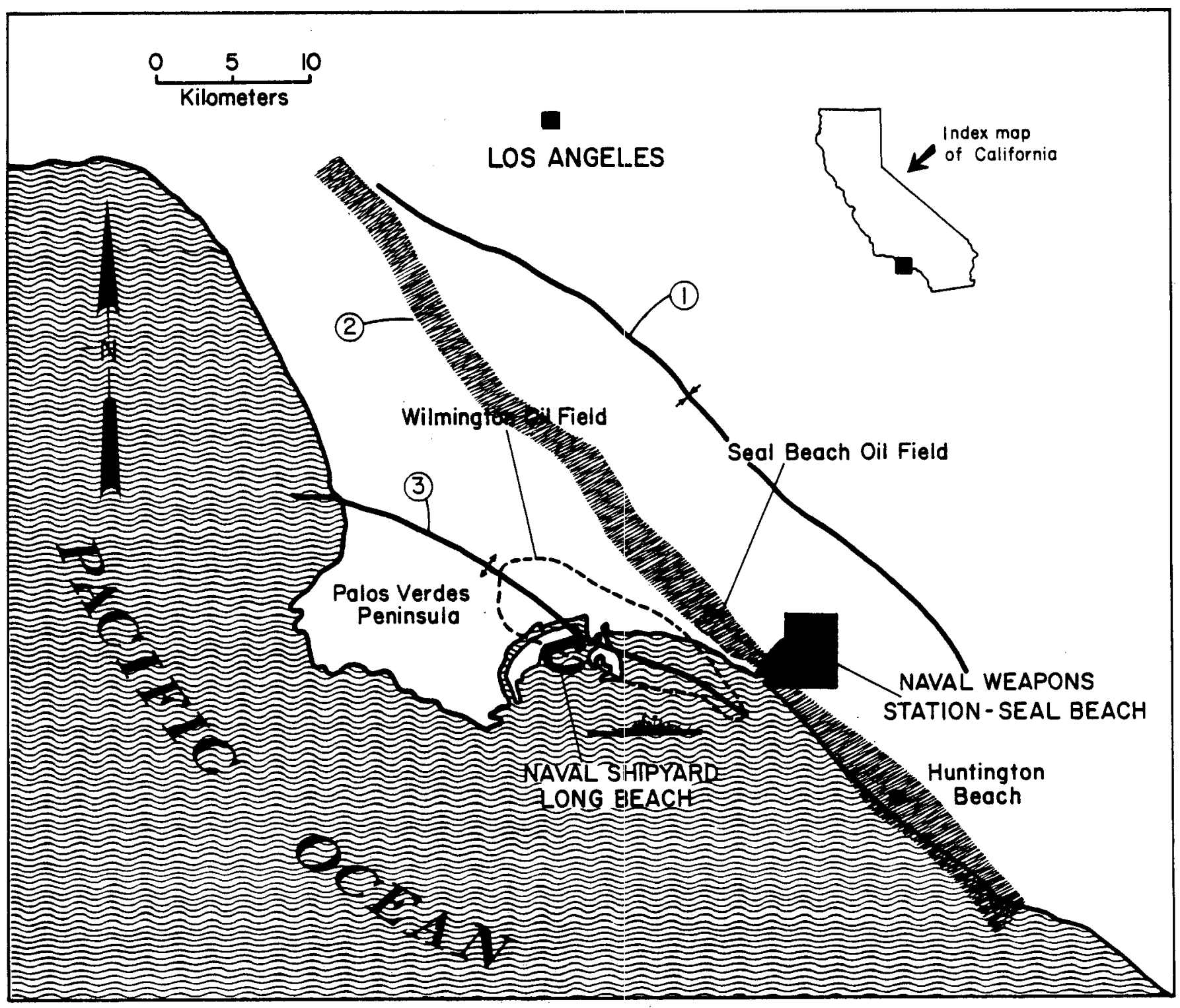

FIGURE 1 - Locations of the Long Beach Naval Shipyard and Naval Station and the Seal Beach Naval Weapons Station relative to the Wilmington $0 i 1$ Field and Seal Beach 0il Field. Principal geologic structures in the Los Angeles basin are 1) Downey syncline, 2) Newport-Inglewood fault zone, and 3) Torrance-Wilmington anticline. 


\section{ACKNOWLEDGMENTS}

Many individuais provided information, assistance, and ideas for this project. Foremost among these were:

California Department of Water Resources - Sanford Werner

California Department of Conservation, Division of $0 i l$ and Gas - Dave Curtis and Rich Manuel

California State Lands Commission - Charles Boquist

City of Long Beach, Department of 0il Properties - Larry 01 son

City of Seal Beach - Gary Johnson and Nate Pendergraft

Long Beach oil Development Company - Richard Smith and Larry Hettick

Orange County Water District - Jim Fairchild

RCU Operator - Doc Crane and John Richardson

U.S. Department of Energy - John Crawford and Bill Holman

U.S. Department of the Navy - Al Katzenstein, Jack Neffew, Carla Gerrard, and Patricia Jones

U.S. Geological Survey - Bill Hardt

The manuscript was critically read by Forrest Bacon, John Alfors, John Crawford, and Jon Lloyd who suggested several improvements. Special thanks to Lois Pickering, Patty Taylor, Danielle Riordan, Cora Pingree, and Yukie Ota for typing the manuscript and to Frances Rubish for drafting the figures and plates. Jack Bennett and Gordon Campbell surveyed several iines on the Seal Beach Naval Weapons Station for measurement of gravity. 


\section{REG IONAL GEOLDGIC SETTING}

STRATIGRAPHY AND STRUCTURE

Both the Long Beach Naval Shipyard and Naval Station and the Seal Beach Naval Weapons Station are situated above what is termed geologically the "Los Angeles basin." In simplified view, this extensive sedimentary basin comprises a Mesozoic crystalline basement overlain by a substantial thickness of predominantly-marine Cretaceous and Cenozoic sedimentary rocks. According to Yerkes and others (1965), depths to the basement range from as little as a few thousand feet near downtown Los Angeles to as much as about 31,000 feet approximately 25 kilometers north-northwest of the Seal Beach Naval Weapons Station.

The basin has been extensively folded and faulted and is dominated structurally by the northwest-trending Downey syncline (Figure 1). To the west, the syncline is disrupted by the Newport-Inglewood fault zone, an active right-lateral wrench zone, which also trends northwest and passes through the southwest part of the Seal Beach Naval Weapons Station. Still farther west is the northwest-trending Torrance-Wilmington anticline above the southwest flank of which are situated the Long Beach Naval Shipyard and Naval Station.

HYDROLOGY

The ground water hydrology of much of the Los Angeles basin has been extensively discussed by Poland (1959), Poland and others (1956), Poland and others (1959), and the California Department of Water Resources $(1961,1967$, 1968). These reports deal mostly with the shallowest aquifers ( $<1500$ feet deep) and are thus not particularly useful for study of the deeper, hotter aquifers of the basin. Information on the deeper aquifers is more sparse and is derived mainly from the drilling and development of oil fields.

Fresh ground water (defined here loosely as water with total dissolved solids less than about 1,000 parts per million) is mainly at depths of less than a few thousand feet in the Los Angeles basin. Below these depths, the sedimentary rocks are saturated with saline waters that were trapped in pore spaces when the sediments were deposited in the oceans that covered the basin millions of years ago. The term "saline", as used here, also includes brackish waters, which typically contain about 1,000-10,000 ppm total dissolved solids and are generally present in the uppermost part of the saline zone. The saline waters have been altered chemically since they were first entrapped but are still dominated by ions of sodium and chloride; the total dissolved solids of most fall in the range of $20,000-35,000 \mathrm{ppm}$.

In general, the base of the fresh-water zone in the basin is considered by most workers to be the base of the Upper P.jiocene Pico Formation and its equivalents. For practical purposes, the base of ground water in the basin is the top of the crystali ine basement, which is inherently impermeable except where open fractures are present.

The hydraulics of the basin's ground water system are important in regard to its potential as a source of geothermal fluids. The proportion of replenishment of the entire body of ground water by surface recharge is small as indicated by the high ratio of sailine water to fresh water in the 
sedimentary section. One reason for this minor contribution is the relatively low precipitation in the Los Angeles area, which averages about 10-15 inches per year. Furthermore, the deeper saline zones of the basin become increasingly cut off with depth from the possibility of surface recharge because of faulting and impermeable shale layers. Thus, the deepest sedimentary rocks contain essentially closed hydrologic systems.

Over much of its length and depth, the Newport-Inglewood fault zone is a semi-permeable to impermeable barrier to the movement of ground water (Poland and others, 1956). Fresh ground water moving westerly is impeded so that water levels are generally higher east of the fault zone. Conversely, in many places, the fault zone prevents intrusion of sea water from the west where excessive pumping of ground water has lowered the fresh-water head.

GEOTHERMAL CHARACTERISTICS

The flow of heat through the Los Angeles basin to the ground surface is largely by conduction. Heat generated in the mantle and crustal basement rocks rises through the overlying predominantly-marine sandstones and shales at an average rate estimated here to be about 70 milliwatts/meter 2 based on two heat-flow measurements in the vicinity of the Los Angeles basin (Higgins, 1980). This quantity is a little above the average heat flow from the earth, where "average" is about 63 milliwatts/meter2.

The abundant shale in the sedimentary section of the basin acts as a blanket of thermal insulation over the basement because of the shale's low thermal conductivity. This low thermal conductivity and the above-average flow of heat from the basement and below have combined to produce a geothermal gradient in the basin that overall is above normal, where "normal" is about $1.7 \mathrm{~F} / 100$ feet or $3.0^{\circ} \mathrm{C} / 100$ meters. Gradients computed by Higgins (1981) for various oil fields in the basin ranged from about 1.7 to $3.1^{\circ} \mathrm{F} / 100$ feet 13.0 to $5.6^{\circ} \mathrm{C} / 100$ meters).

In comparison of geothermal gradients to depths to basement, it appears that gradients are highest over structural highs (anticlines) and lowest over structural lows (synclines). The explanation for this may be that in the former, the highly conductive basement rocks are closer to that part of the sedimentary section where temperatures are normally measured. If depth to basement is too shallow, however, there will be insufficient thermal insulation by overlying sedimentary rocks (sedimentary rocks are too thin) to sustain high gradients (Higgins, 1981). Preliminary observations suggest that the optimum depth to basement for the highest geothermal gradients in the Los Angeles basin is about 4,000-6,000 feet.

Despite the above-normal geothermal gradient and heat flow in the Los Angeles basin, there are few known convective geothermal anomalies. A few thermal springs $\left(<120^{\circ} \mathrm{F}\right)$ discharge on the Palos Verdes Peninsula (Figure 1$)$, but their low temperatures and flow rates indicate they are of minor importance. There are a few thermal water wells in the basin (Higgins, 1981), but they are only marginally warm and may reflect more the depth of the wells rather than truly anomalous geothermal conditions. Finally, high-temperature geothermal systems related to shallow igneous intrusions are apparently absent; the youngest known volcanic rocks in the Los Angeles basin are Miocene (>6 million years $01 \mathrm{~d}$ ), which are too old to produce present-day geothermal anomalies. 
During the late 1940 's, an exploratory oil well, Seguro No. 1, reportedly encountered temperatures estimated at $424^{\circ} \mathrm{F}$ at approximately 9,100 feet in the Huntington Beach 0il Field, about 10 kilometers southeast of the Seal Beach Naval Weapons Station (Figure 1). Such high temperatures have not been duplicated anywhere else, however, in the thousands of oil wells that have been drilled in the LOS Angeles basin. Apparently. Seguro No. 1 fortuitously intersected an open fracture in the Newport-Inglewood fault zone that contained thermal water derived from much greater depths in the earth's crust. 
LONG BEACH NAVAL SHIPYARD AND NAVAL STATION

PHYSICAL SETTING

The Long Beach Naval Shipyard and Naval Station occupy a portion of heavily industrialized Terminal Island, which is the nucleus of the Los Angeles-Long Beach harbor ( $P$ late 1 ). The base is about 3 kilometers southwest of downtown Long Beach. Major activities at the base include the maintenance and repair of warships, at a large complex of drydocks, and the supply of warships at the adjacent station. The surrounding commercial harbor is one of the busiest in the world and both it and the naval base are partly within Wilmington 0il Field, the largest cumulative oil-producer in California.

SUBSURFACE GEOLOGY

Because the naval base is entirely covered by Quaternary alluvium and artificial fill, the subsurface stratigraphy and structure have been deciphered mostiy by oil-well drilling and geophysical exploration.

Stratigraphy

In a general way, the stratigraphy beneath the naval base is, with minor differences, the same as that of the Los Angeles basin as a whole (Figure 2). Here, the basement is schistose (Catalina Schist) and is overlain to a depth of about 5,900-8,500 feet by alternating sandstones, shales, and some conglomerates of Tertiary and Quaternary age. The Upper Miocene Puente Formation and the Lower Pliocene Repetto Formation comprise most of these sedimentary rocks. The various oil-producing zones within the sedimentary section are shown in Figure 2.

Depth to basement is shallowest beneath the northeast corner of the naval base (Pier $E$ ) and steadily increases to the southwest (Figure 3 ).

Structure

The entire area of the naval base overlies part of the southwest 1 imb of the asymmetric Torrance-Wilmington anticline, the axis of which is just beyond the northeast corner of the naval base (Figure 4 ). The folding affects only the Repetto and older formations. Beds of the southwest 1 imb dip about $15^{\circ}-25^{\circ}$ on the average and thicken away from the axis of the anticline, which suggests that growth of the anticline was concurrent with deposition.

Beds younger than the Repetto Formation are largely undeformed by faults. The Repetto and older formations are extensively fractured by a group of north-trending normal faults, several of which pass beneath the naval base (Figure 4, Plate 1). The largest faults are boundaries for several "fault blocks" designated by Roman numerals. Portions of fault blocks I, II, III, and IV underlie the naval base. The Cerritos fault is the boundary between blocks II and III and dips easterly about $45^{\circ}$ (Mayuga, 1970). The Powerline fault is the boundary between blocks III and IV and dips westerly about $55^{\circ}$ (Mayuga, 1970). At depth, the Cerritos fault eventually cuts off fault block III beneath the naval base. The extent and character of the faults in the schist basement are unknown because of limited drilling and poor stratigraphic control. 


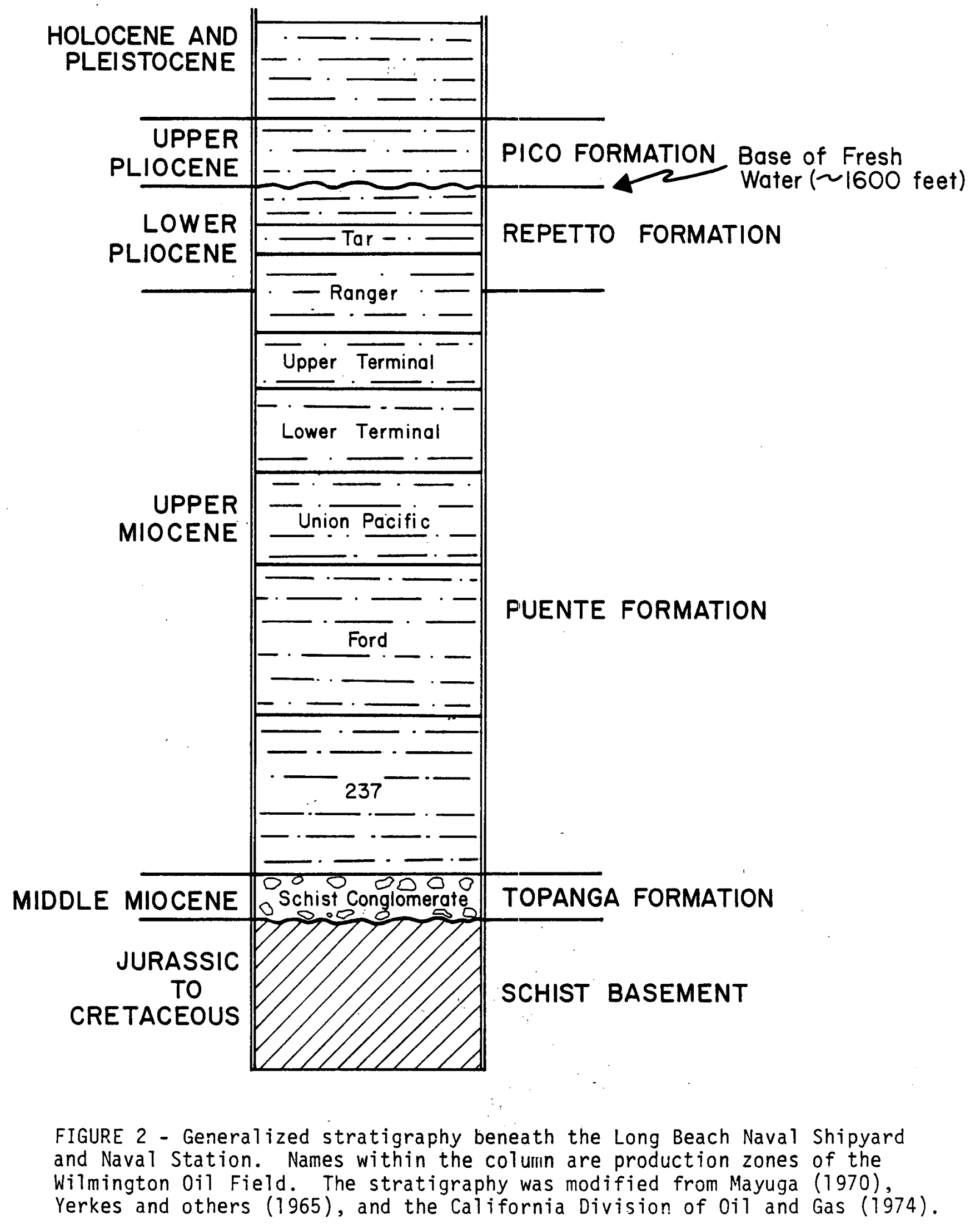




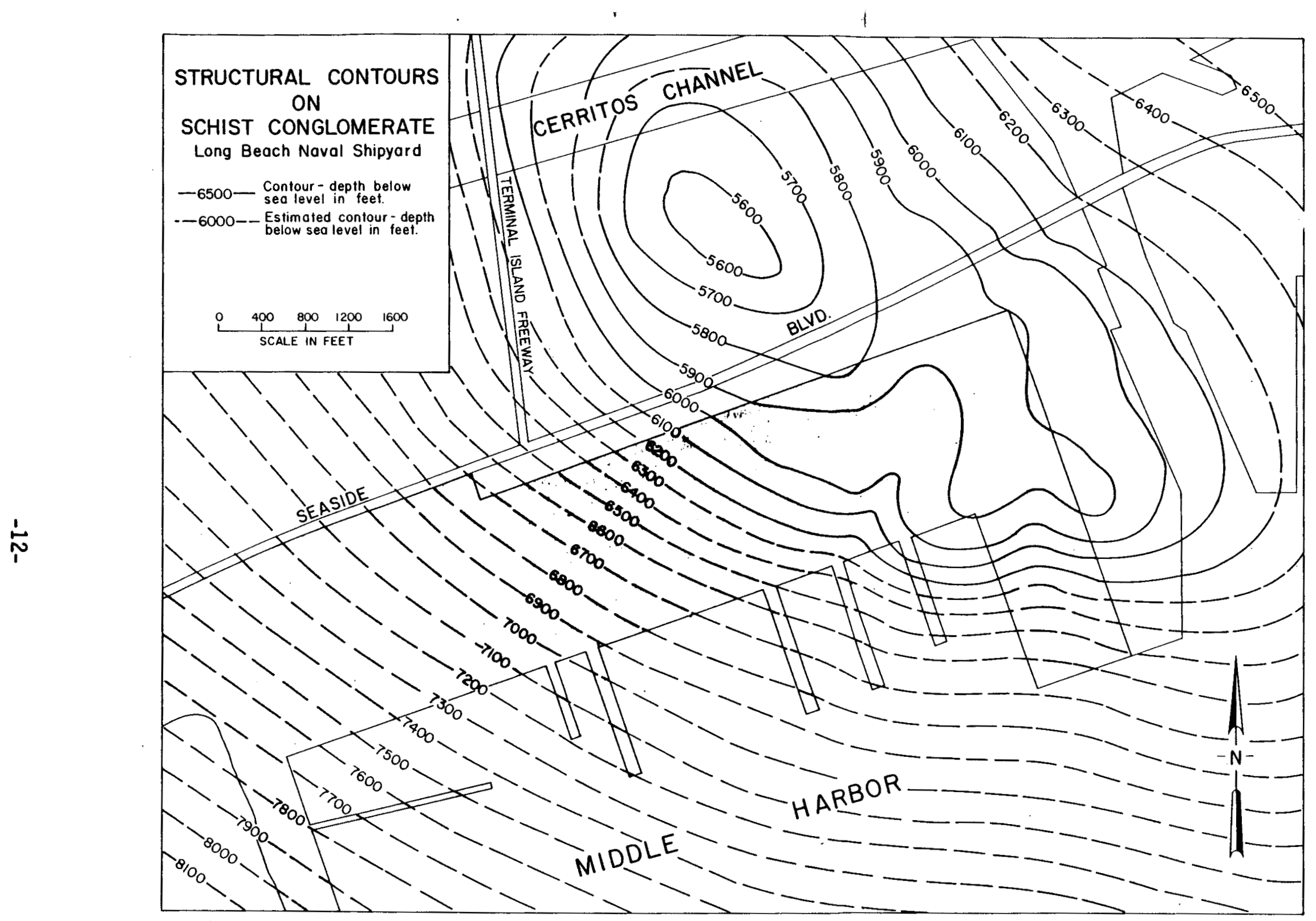

FIGURE 3 - Structural contours on top of the Schist Conglomerate, which essentially represents depth to basement. Main part of the Long Beach Naval Shipyard and Naval Station is shaded. The data are modified from an unpublished field map (1982) of the Long Beach $0 i 1$ Development Company. 

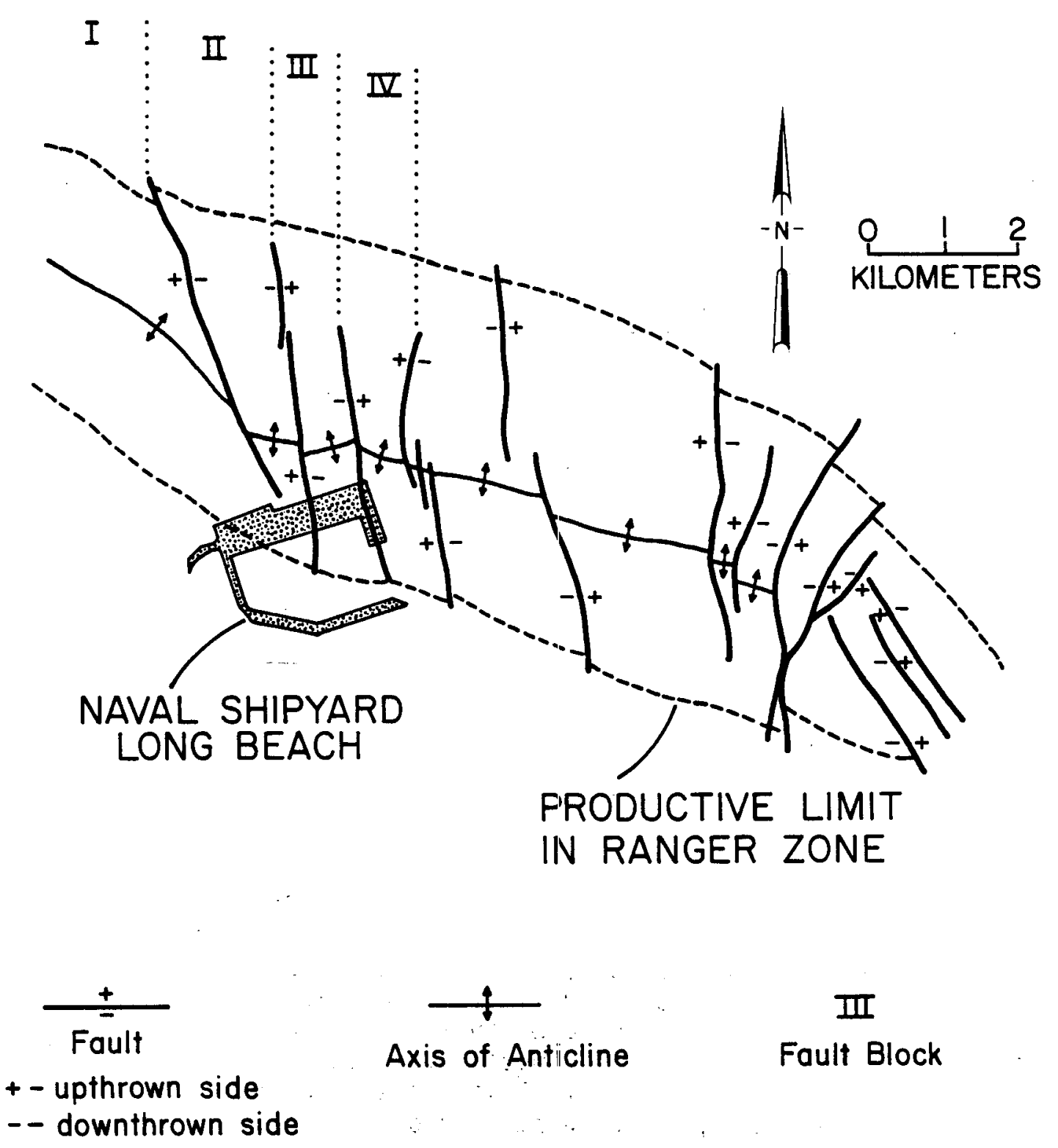

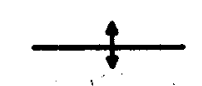

Axis of Anticline
III

Fault Block

FIGURE 4 - Structure of the Wilmington 0il Field in the vicinity of the Long Beach Naval Shipyard and Naval Station. Both the productive 1 imit and faults through the top of the Ranger zone are shown. The data are after the California Division of $0 i 1$ and Gas (1974). 
Figure 5 is the only known curve of geothermal gradient for the central area of the Wilmington 0il Field, which includes the part of the field that underlies the naval base. The curve was compiled in 1949 from 84 temperature surveys measured in oil wells in the field. At this time, the solid-line segment of the curve had $\mathrm{a}$ gradient of about $3.1^{\circ} \mathrm{F} / 100$ feet $\left(5.6^{\circ} \mathrm{C} / 100\right.$ meters), which is almost twice the earth's average. The gradient is also equal to the highest known in the Los Angeles basin and probably results from the optimum combination of a shallow basement high insulated by sedimentary rocks of low thermal conductivity.

More recently, the Tar, Ranger, and Upper Terminal zones have been extensively flooded with water of somewhat variable temperature for purposes of secondary recovery of oil and control of subsidence. As a result, the geothermal gradient in these zones may differ (probably lessens) from that computed in 1949. Because there has been little or no water-flooding in the deeper zones (Lower Terminal, Union Pacific, Ford, 237, and Schist Conglomerate), the 1949 gradient is probably still valid below the Upper Terminal zone. The base of the Upper Terminal zone ranges from about 3,500 feet deep beneath the nor theast part of the naval base to over 5,000 feet deep beneath the southwest part.

A temperature of $212^{\circ} \mathrm{F}$ (boiling point of water at sea level) is expected at a depth of approximately 5,300 feet under the naval base. At the shallowest depth $(5,900$ feet) of the contact between the basement and sedimentary rocks beneath the naval base, temperatures are probably about $230^{\circ} \mathrm{F}$. At the deepest point of this contact, temperatures may be about $325^{\circ} \mathrm{F}$, assuming that there is little lateral decrease of the 1949 gradient away from the axis of the anticline, where the gradient was surveyed.

PHYSICAL AND CHEMICAL PROPERTIES OF THE ROCK UNITS

Shallow (Fresh-Water) Sediments

The unconformable contact between the Upper Pliocene Pico Formation and the underlying Lower Pliocene Repetto Formation is the approximate lower limit of fresh-water aquifers beneath the naval base. This 1 imit ranges from about 1,600 to 1,900 feet in depth (Plate 1). Above these depths, there are several unconsolidated sand and gravel aquifers, which are unaffected by the extensive block-faulting of the Torrance-Wilmington anticline. The scarcity of faults allows unimpeded hydrologic continuity within the sediments. This continuity, in combination with the lack of consolidation of the sediments, results in aquifers capable of producing large quantities of water, some of which is saline. The salinity has been caused by excessive pumping of ground water in the area, which allowed sea water to invade formerly fresh-water aquifers.

Temperatures of water in these shallow zones are expected to be no more than about $100^{\circ} \mathrm{F}$. A group of water wells at the Southern Cal ifornia Edison Company's power plant just north of the naval base, had recorded temperatures in the range of $70^{\circ}-79^{\circ}$. F during several years of measurement (California Department of Water Resources, 1980). A temperature of $98^{\circ} \mathrm{F}$ measured in one of those wells by the Department of Water Resources (1980) is considered spurious. 


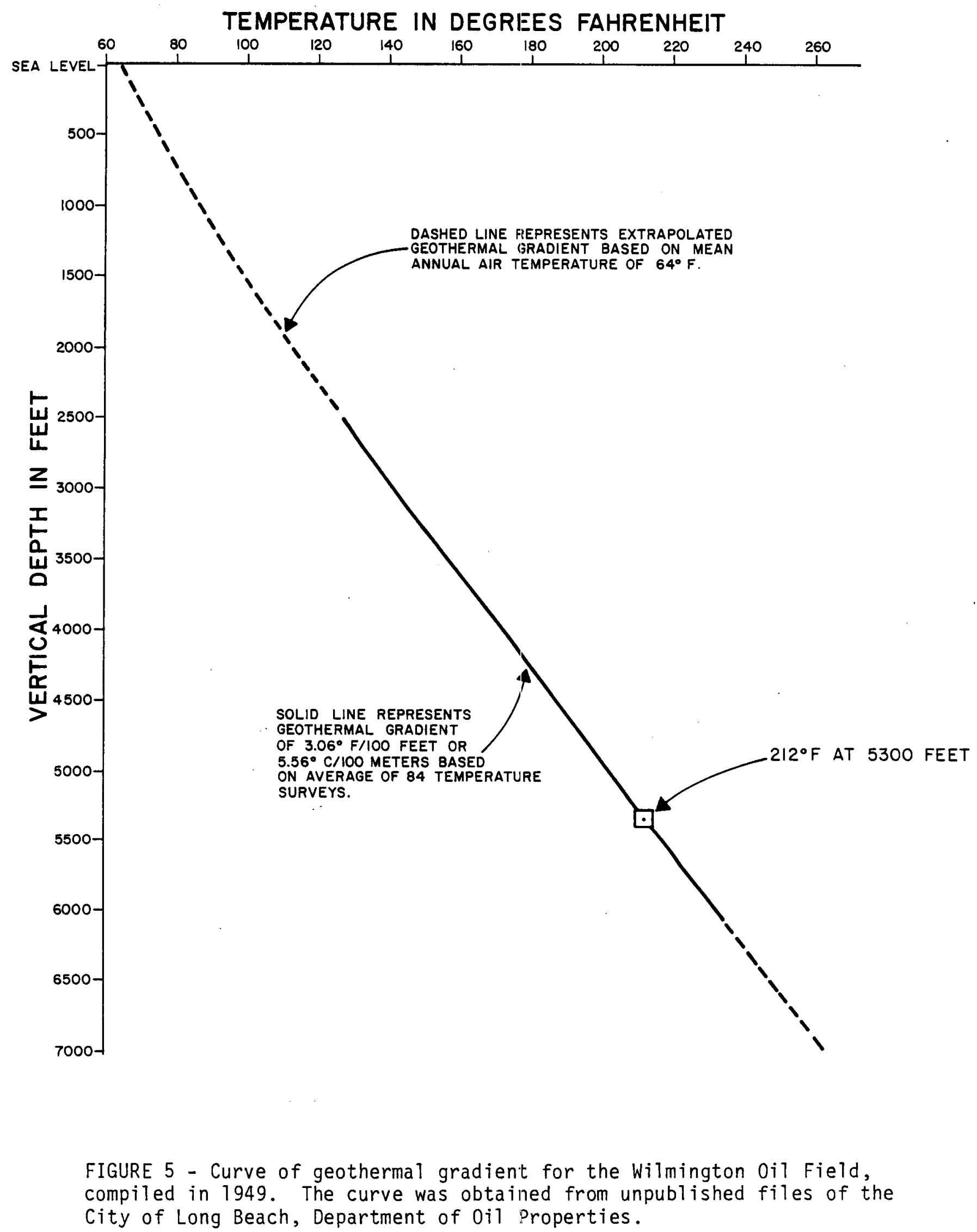


Below the Pico Formation, the sedimentary rocks are more consolidated, hotter, and saturated with saline water. $0 i 1$ is produced from 8 zones, which extend almost continuously from the base of the $P$ ico Formation to the top of the crystalline basement (Figure 2).

Average reservoir properties of the 8 zones are compiled in Table 1 . Each zone is generally several hundred feet thick and consists mainiy of

alternating sandstones and shales in about equal volumes; the former generally serve as reservoirs for the oil. In general, porosities and permeabilities decrease with depth. Originaliy, reservoir pressures increased with depth, but have since been reduced by the production of oil. The range of permeabilities (100-1,600 millidarcies) is low to moderate. The permeability of the schist conglomerate is unknown, but could be locally high where extensively fractured. The gravity of oil produced increases with depth and probably reflects the increase in temperature. Total dissolved solids in waters of the different zones range from about 17,000 to $34,000 \mathrm{ppm}$. A11 waters are of the sodium chloride type, which is particularly corrosive. Typical chemical analyses from a few of the upper zones are presented in Table 2.

\section{Basement}

The crystalline basement is expected to be largely nonwater-bearing because it is inherently impermeable. Open fractures in the basement may allow movement of ground water, but the total volume will be very small compared to that in the overlying sedimentary rocks. 
TABLE 1 - Physical and chemical properties of oil-producing zones in the Wilmington 0il Field, as modified from Mayuga (1970) and unpublished records of the California Division of 0il and Gas.

\begin{tabular}{|c|c|c|c|c|c|c|c|c|c|}
\hline ZONE & $\begin{array}{l}\text { SHALLOWEST DEPTH } \\
\text { TO TOP OF ZONE* } \\
\text { (Feet) }\end{array}$ & $\begin{array}{c}\text { AVERAGE } \\
\text { TEMPERATURE } \\
\left({ }^{\circ} \mathrm{F}\right)\end{array}$ & $\begin{array}{l}\text { AVERAGE } \\
\text { THICKNESS } \\
\text { (Feet) }\end{array}$ & $\begin{array}{l}\text { APPROXIMATE } \\
\text { AVERAGE } \\
\% \text { SAND }\end{array}$ & $\begin{array}{c}\text { INITIAL RESERVOIR } \\
\text { PRESSURE } \\
\text { (pSi) }\end{array}$ & $\begin{array}{l}\text { AVERAGE } \\
\text { POROSITY } \\
(\%)\end{array}$ & $\begin{array}{c}\text { AVERAGE } \\
\text { PERMEABILITY } \\
\text { (Md) }\end{array}$ & $\begin{array}{c}\text { GRAVITY OF } \\
\text { OIL } \\
\text { ('API) }\end{array}$ & $\begin{array}{l}\text { TDS IN } \\
\text { WATER } \\
(\mathrm{ppm})\end{array}$ \\
\hline Tar & 2200 & 118 & 300 & 40 & 1040 & $30-40$ & $1000-1600$ & $12-15$ & 28,000 \\
\hline Ranger & 2500 & 127 & 500 & $>30$ & 1210 & 35 & $700-1600$ & $12-25$ & 31,700 \\
\hline Upper Terminal & 3000 & 142 & 500 & $50-70$ & 1390 & $32-35$ & 700 & $14-25$ & 32,600 \\
\hline Lower Terminal & 3500 & 157 & 500 & $50-70$ & 1610 & $30-33$ & $450-500$ & $20-31$ & 32,000 \\
\hline Union Pacific & 4000 & 172 & 500 & $20-25$ & 1950 & $20-30$ & $150-190$ & $25-32$ & 34,200 \\
\hline Ford & 4500 & 187 & 1000 & $20-25$ & $2150 ?$ & 25 & 100 & $28-32$ & 25,700 \\
\hline 237 & 5500 & 218 & 400 & 40 & 2567 & 25 & 275 & $28-32$ & 23,900 \\
\hline Schist Conglomerate & 5900 & 230 & $<100$ & $?$ & $2750 ?$ & $20-25 ?$ & $<500 ?$ & $28-32$ & 17,100 \\
\hline
\end{tabular}


TABLE 2 - Chemistry of waters produced from selected zones in the Wilmington 0il Field, as modified from unpublished records of the California Division of $0 i 1$ and Gas.

\begin{tabular}{|c|c|c|c|c|c|c|c|c|c|c|c|c|c|c|c|c|}
\hline ZONE & DATE & $\mathrm{pH}$ & $\mathrm{Na}$ & $\mathrm{NH}_{4}$ & $\mathrm{Ca}$ & $\mathrm{Mg}$ & $\mathrm{Ba}$ & $\mathrm{Fe}$ & $\mathrm{SO}_{4}$ & $\mathrm{Cl}$ & $\mathrm{HCO}_{3}$ & $\mathrm{CO}_{3}$ & $\mathrm{~B}_{4} 0_{7}$ & I & $\mathrm{SiO}_{2}$ & TDS \\
\hline Tar & $8 / 10 / 65$ & 7.6 & 11,640 & 88 & 322 & 280 & 25 & $T$ & 0 & 19,290 & 226 & 0 & 181 & 76 & 37 & 32,165 \\
\hline Ranger & $8 / 10 / 65$ & 7.7 & 10,050 & 190 & 349 & 265 & 19 & $<0.1$ & $<2.0$ & 16,880 & 525 & 0 & 129 & 127 & 43 & 28,577 \\
\hline $\begin{array}{l}\text { Lower } \\
\text { Terminal }\end{array}$ & $5 / 19 / 72$ & 7.5 & 10,740 & 170 & 535 & 235 & 44 & 2 & $T$ & 18,085 & 590 & 0 & 245 & 70 & 80 & 30,835 \\
\hline
\end{tabular}


Most of the naval base is underlain by one or more of the productive oil zones described previously. Several oil companies operate wells and surface facilities just north and east of the base (Figure 6, P1ate 1); many wells are slant-drilled beneath the base. Most oill and associated water are produced from the Tar, Ranger, Upper Terminal, and Lower Terminal zones. Relatively small amounts are produced from the 4 deeper zones.

Because the oil wells produce oil and water from several thousand feet deep, the temperature of the $0 i 1$ and water is elevated and in some cases hot depending on the depths of zones of production and the rate of production of each well. The hot fluid from each well is piped to centralized collection and disposal facilities, which process large volumes of oil and water daily. The combination of el evated temperature and large volume of fluid make the oilfield operations in Wilmington 0il Field a ready-made source of geothermal energy.

Production and Injection Wells

A group of about 175 production and injection wells along the north perimeter of the naval base and on Pier $E$ is operated by the Long Beach $0 i 1$ Development Company (LBOD) as its "W" lease (Figure 6, Plate 1). North of Seaside Boulevard, Champl in Petroleum Company and, to a lesser extent, Mobil oil Corporation and Exxon Company, U.S.A. have oil leases with many wells. of these four companies, the operations of L.BOD and Champlin are of primary interest as possible sources of thermal energy for the naval base. The Mobil and Exxon operations will not be discussed further because of their smaller size and greater distance from the base.

The important variables in the consideration of individual wells near the naval base as sources of thermal energy are temperature and rate of production or injection. In November 1983, well-head temperatures were measured on 13 production wells on LBOD's "W" lease; the wells were selected based on their rates and zones of production (Table 3 ). The temperatures ranged from $86^{\circ}$ to $161^{\circ} \mathrm{F}$ with most between $115^{\circ}$ and $125^{\circ} \mathrm{F}$. Wells $236 \mathrm{~B}, 285 \mathrm{~A}$, and 289 were selected in particular because of their high rates of production compared to all other wells on the lease. It was thought that the high rates might be influenced by contributions from permeable fault zones with access to relatively high-temperature fluids. The temperatures in these 3 wells ranged only from $118^{\circ}-123^{\circ} \mathrm{F}$, however. The well $(328 \mathrm{~A})$ with the highest temperature of the 13 had an average production of $12 \mathrm{gal} /$ minute from the low-permeability Ford zone. We suggest that the 13 measured temperatures are representative of all the LBOD production wells and that most, if not all, well-head temperatures will fall wi.thin the reported range.

Most production wells produce fluids with standard beam-rod pumps, which are designed for relatively small rates of production. Higher rates are attained in the few wells with bottom-hole electric pumps. The range of production rates for wells on LBOD's. "W" lease during September 1983 was about 1 gal/minute to almost 100 gal/minute (well 289); most wells produce less than $20 \mathrm{gal} / \mathrm{minute.} \mathrm{Because} \mathrm{this} \mathrm{part} \mathrm{of} \mathrm{the} \mathrm{oil} \mathrm{field} \mathrm{has} \mathrm{been} \mathrm{in} \mathrm{production} \mathrm{for}$ many decades, the percentage of water produced with the $0 i 1$ from the wells is very high, generally more than $90 \%$. 


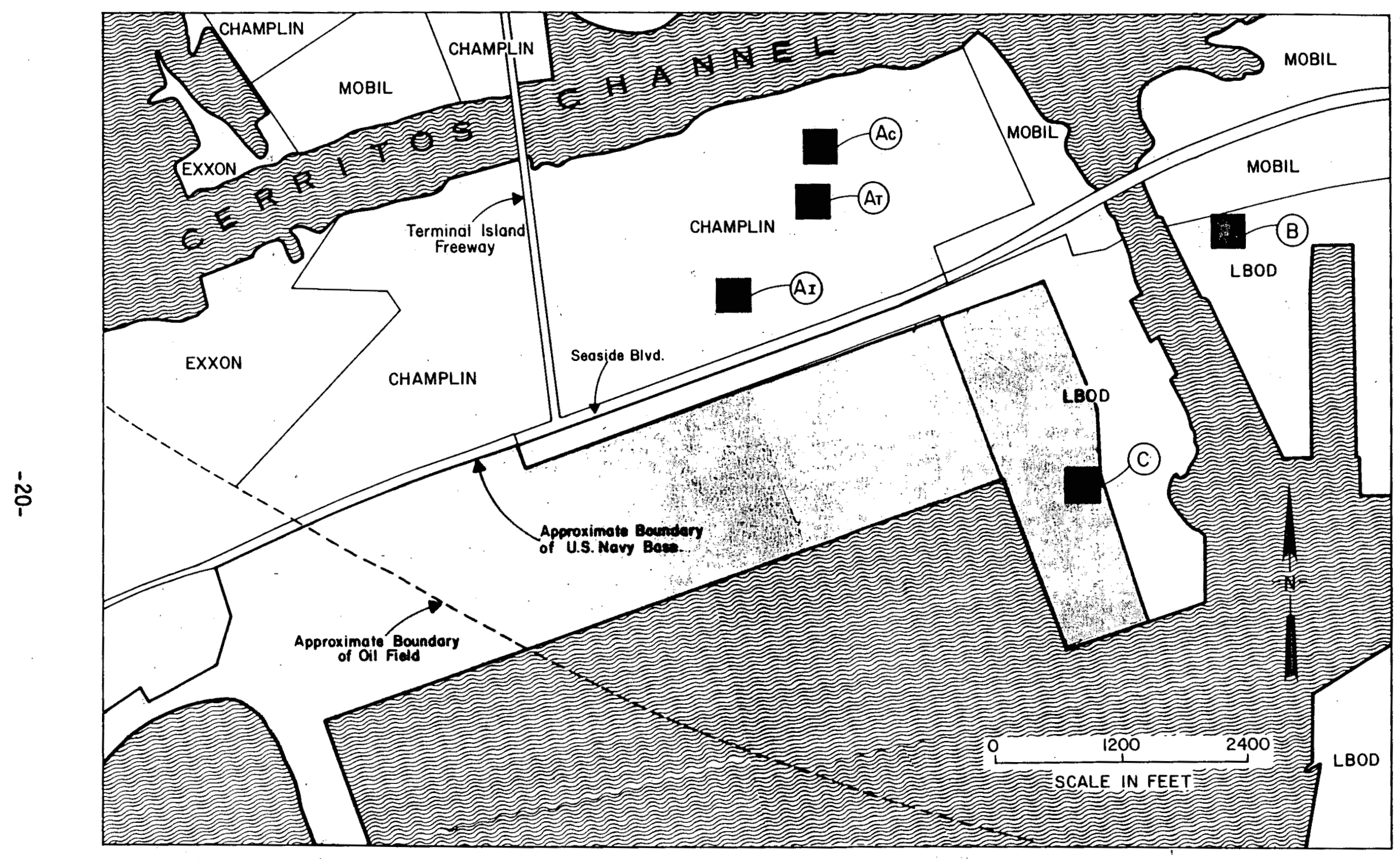

FIGURE 6 - Locations of oil field leases and central processing facilities on or adjacent to the Long Beach Naval Shipyard and Naval Station. Names of operators are shown on the leases. Facilities are as follows: $A_{C}-$

"Island" collection unit, $A_{T}$ - "Island" water treatment unit, $A_{I}$ -

"Island" injection plant, $B$ - "XY" collection and injection facility,

C - "Pier E" injection plant. The naval base is shaded. 
TABLE 3 - Well-head temperatures and rates of production from selected oil wells on the LBOD "W" lease on and adjacent to the Long Beach Naval Shipyard and Naval Station. The temperatures were measured in November 1983. The volumes are averages for September 1983, as provided by the Long Beach $0 i 1$ Development Company.

\begin{tabular}{ccc} 
WELL & TEMPERATURE $\left({ }^{\circ} \mathrm{F}\right)$ & VOLUME $(\mathrm{GAL} / \mathrm{MIN})$ \\
\cline { 2 - 3 }$=328 \mathrm{~A}$ & $161^{\circ}$ & 12 \\
$138 \mathrm{~B}$ & $145^{\circ}$ & 14 \\
$35 \mathrm{D}$ & $136^{\circ}$ & 34 \\
$248 \mathrm{~A}$ & $124^{\circ}$ & 29 \\
$236 \mathrm{~B}$ & $123^{\circ}$ & 70 \\
$29 \mathrm{C}$ & $122^{\circ}$ & 14 \\
214 & $122^{\circ}$ & 7 \\
$285 \mathrm{~A}$ & $118^{\circ}$ & 61 \\
289 & $118^{\circ}$ & 98 \\
$142 \mathrm{~B}$ & $117^{\circ}$ & 19 \\
$131 \mathrm{~A}$ & $104^{\circ}$ & 9 \\
$79 \mathrm{C}$ & $100^{\circ}$ & 2 \\
$98 \mathrm{~B}$ & $86^{\circ}$ & 2
\end{tabular}


Several dozen injection wells are distributed throughout the "W" 1 ease (Plate 1). Rates of injection ranged from 9 to 206 gal/minute in September 1983; the average of the 41 injection wel1s on line during the month was 61 gal/minute. The temperature of the injected water was about $100^{\circ} \mathrm{F}$.

Collection and Disposal of Fluids

A11 fluids produced from the oil wells on and adjacent to the naval base are transported to centralized facilities for processing and disposal. These facilities perform one or all of the following: collection of produced oil and water, separation of oil and water, treatment of water for disposal, and distribution of water to wells for subsurface injection. In the latter process, all waters are injected into production zones to aid recovery of oil.

Figure 6 and Plate 1 show the locations of central facilities on or adjacent to the naval base. Table 4 lists the volumes, temperatures, and amounts of thermal energy of the water processed in each facility.

All fluids produced from LBOD's "W" lease on Terminal Island are transported to Champlin Petroleum's "Island" processing facility, which comprises 3 individual units. In 1981, the collection unit (Ac on Plate 1) handled about $7,000 \mathrm{gal} / \mathrm{minute}$ of water at approximately $115 \mathrm{~F}$, while the injection unit $\left(A_{I}\right)$ distributed over 5,000 gal/minute at about $112^{\circ} \mathrm{F}$. Production from LBOD's " $X$ " and " $Y$ " leases on the piers east of Pier $E$ is processed and distributed at that company's "XY" facility, which is east of Terminal Is/and. In 1981, about 1,400 gal/minute of water were processed there with an average drop in temperature from $125^{\circ}$ to $104^{\circ} \mathrm{F}$. A third facility is the "Pier E" injection plant operated by LBOD. This plant injects about 1,000-1,300 gal/minute of water at approximately $100^{\circ} \mathrm{F}$ into production zones underlying the naval base. The source of this water is a pair of shallow water wells on the Champlin lease, which tap a shallow aquifer intruded by sea water.

The thermal energy of processed water in these facilities is estimated in Btu/hour based on the difference between the water's initial temperature at the facility and a final temperature of $64^{\circ} \mathrm{F}$, which is the mean annual air temperature. The equation is:

$$
E^{\prime}=(v)(k)\left(T_{j}-T_{f}\right)(t)(s)
$$

$$
\begin{aligned}
& \text { where } E=\text { Btu/hour (heat lost when } 1 \mathrm{lb} \text {. of water loses } 1 \mathrm{~F}^{\circ} \text { in } \\
& \text { temperature), } \\
& v=\text { volume of water in gal/minute, } \\
& k=\text { weight of one galion of water }=8.33 \mathrm{lb} . \text {, } \\
& T_{j}=\text { initial temperature of water in facility, } \\
& T_{f}=\text { final temperature of water after extraction of heat }= \\
& 64^{\circ} \mathrm{F} \text {, } \\
& t=60 \text { minutes/hour, } \\
& s=\text { specific heat of water }=1 \mathrm{Btu} / 7 \mathrm{~b} .-\mathrm{F}^{\circ} \text { (Variations in this } \\
& \text { constant caused by high salinity and temperature of the } \\
& \text { water are considered negligible for the purposes of this } \\
& \text { calculation.) }
\end{aligned}
$$

The energy at these facilities, assuming that sufficient heat were extracted to lower the water temperature to $64^{\circ} \mathrm{F}$, is in the range of 
TABLE 4 - Temperatures, volumes, and thermal energy of water processed in the central oil field facilities on and adjacent to the Long Beach Naval Shipyard and Naval Station. Figures for the "XY" and "Island" facilities were reported by the operators for 1981, the "Pier E" figures for 1983. "I" means that the water was injected as part of secondary-recovery (waterflood) programs.

\begin{tabular}{|c|c|c|c|c|c|c|c|c|}
\hline FIELD & $\begin{array}{l}\text { OPERATOR } \\
\text { AND FACILITY } \\
\end{array}$ & $\begin{array}{c}\text { WATER } \\
\text { PRODUCTION } \\
\text { (gal/min) } \\
\end{array}$ & $\begin{array}{l}\text { TEMPERATURE } \\
\left({ }^{\circ} \mathrm{F}\right)\end{array}$ & $\begin{array}{l}\text { BTU/HOUR } \\
\text { @ } \mathrm{T}_{\mathrm{F}}=64^{\circ} \mathrm{F}\end{array}$ & $\begin{array}{c}\text { WATER } \\
\text { DISPOSAL } \\
\text { (gal/min) } \\
\end{array}$ & TYPE & $\begin{array}{c}\text { TEMPERATURE } \\
\left({ }^{\circ} \mathrm{F}\right)\end{array}$ & $\begin{array}{l}\text { BTU/HOUR } \\
\text { @ } T_{F}=64^{\circ} \mathrm{F}\end{array}$ \\
\hline \multirow{3}{*}{ WILMINGTON } & $\begin{array}{l}\text { LBOD } \\
\text { "Pier E" }\end{array}$ & $\longrightarrow$ & $\longrightarrow$ & - & $1,000-1,300$ & I & $100^{\circ}$ & $\begin{array}{l}1.80 \times 10^{7}- \\
2.34 \times 10^{7}\end{array}$ \\
\hline & $\begin{array}{l}\text { LBOD } \\
\text { "XY" }\end{array}$ & 1,400 & $125^{\circ}$ & $4.27 \times 10^{7}$ & 1,400 & I & $104^{\circ}$ & $2.80 \times 10^{7}$ \\
\hline & $\begin{array}{l}\text { Champlin } \\
\text { "Island" }\end{array}$ & 7,000 & $115^{\circ}$ & $17.84 \times 10^{7}$ & 5,200 & I & $112^{\circ}$ & $12.48 \times 10^{7}$ \\
\hline
\end{tabular}


$10^{7}-10^{8} \mathrm{Btu}$ /hour. Higher values of $\mathrm{T}_{f}$, of course, will reduce the energy considerably; consequently, the quantities calculated in Table 4 must be considered maxima in determining the amount of thermal energy available at each facility. Nevertheless, these calculations indicate that the "I sland" facility has about 4 times the thermal energy of the "XY" facility and 5-10 times the energy of the "Pier E" facility.

DRILLING OF WELLS TO PRODUCE THERMAL WATER

One way to develop and use the geothermal energy that underlies the Long Beach Naval Shipyard and Naval Station is to drill one or more wells specifically to produce thermal water. We discuss here many factors that must be considered if the drilling of such wells is to be a serious alternative.

\section{Temperature}

Despite the relatively high geothermal gradient beneath the naval base, temperatures are insufficient above a depth of about 6,000 feet to generate electricity. They are sufficient, however, for some nonelectrical uses of heat. Generally, temperatures of about $300^{\circ} \mathrm{F}$ or more are necessary for generation of significant amounts of electricity, al though some well-head generators can produce small amounts of electricity from water of about $230^{\circ} \mathrm{F}$.

Because of time lag due to pumping of water from depths of several thousand feet, there will be some loss of heat by conduction. The faster the pumping rate, the less loss of heat. This effect is also more pronounced the higher the initial reservoir temperature and the longer the distance the water has to travel to the well-head.

Permeability

Al though temperature increases with depth beneath the naval base, permeability generally decreases such that permeabilities below about 4,000 feet are relatively low except for 1ocal fractured parts of the Schist Conglomerate. This decrease significantly limits the amount of thermal water a well could produce and may offset the advantage of high temperature. Permeabilities are highest (up to 1,600 md) in the Tar and Ranger zones, but temperatures are only about $150^{\circ} \mathrm{F}$ or less.

Locally, the Schist Conglomerate zone is probably capable of producing higher volumes than the overlying 237, Ford, and possibly Union Pacific zones, all of which have poor permeabilities. Elsewhere in the Los Angeles basin, the Schist Conglomerate and its equivalents produce hot $0 i 1$ and water from depths equal to or greater than those at Wilmington 0il Field. As an example, in 1981, one well in the Lawndale 0il Field, about 15 kilometers nor thwest of Terminal Island, was producing about $75 \mathrm{gal} / \mathrm{minute}$ of near-boiling water from the Schist Conglomerate at a depth of approximately 8,000 feet (Higgins, 1981). Another example is the Venice Beach 0il Field, about 35 kilometers northwest of Terminal Island, where 5 wells drilled into an equivalent of the Schist Conglomerate were producing a total of about 235 gal/minute of $220^{\circ}-240^{\circ} \mathrm{F}$-water from a depth of approximately 5,500 feet (Higgins, 1981); the operator reported (personal communication, 1981) that the production zone had a very strong water drive. Both the Venice Beach and Lawndale 0il Fields lie on a basement high similar to that at Wilmington $0 i 1$ Field. 
The comparison between the Schist Conglomerate zone beneath the naval base and the zones in the two oil fields farther northwest suggests that the former may be capable of producing moderate quantities of above-boiling water. In places, these quantities could be as high as $100 \mathrm{gal} /$ minute or more for a well with a bottom-hole pump. The main attraction of the Schist Conglomerate, of course, is that it is the hottest sedimentary zone beneath base. Another advantage is that the water in the zone has the lowest total dissolved solids of any of the oil-producing zones.

Recharge

To sustain sufficient rates of production of thermal water from beneath the naval base, it will be necessary to use pumps; the natural water drive will probably be depleted by long-term production of thermal water, if not already done so by $0 i 1$ production.

It is not clear to what extent the saline-water-bearing zones of the ground water reservoir can be naturally recharged as water is pumped from them at high rates. As discussed earlier, the shallow fresh-water recharge from the ground surface extends only to a few thousand feet maximum depth and is limited by the relatively sparse rainfall in the area. Furthermore, with increasing depth, the fracturing and isolation of water-bearing zones become more complex and effective, respectively, such that many or all of the zones with the highest temperatures also have the least likel ihood of any recharge as they are depleted. The isolation is evident from Mayuga's (1970) observation that faults in the Wilmington 0il Field prevent fluid migration and communication of pressure. As a result, if there is no natural recharge to the system at the depths considered for production of thermal water, there will be a decline in reservoir pressure and subsidence may occur. Correspondingly, rates of production will decrease.

Effects on Production of 0 il

The withdrawal of large amounts of water from beneath the naval base could disrupt current production of oil unless it can be demonstrated that the zone that produces thermal water is hydrologically isolated from the zones that produce oil. This requirement of isolation leaves essentially only the deeper zones as candidates for production. As discussed above, however, these same zones, because of that isolation, may be unable to sustain production.

Subsidence caused by withdrawal of fluid from the oil zones has been a critical problem in the Wilmington 0il Field. The maximum amount (eventually almost 30 feet) occurred beneath the champlin lease, north of the naval base, during the 1940's and $1950^{\prime} \mathrm{s}$. Since then, subsidence has largely been arrested by injection of saline water, derived from oil production and shallow aquifers, into the production zones. At Wilmington 0il:Field, the injection serves two other purposes: (1) it disposes of the large quantities of water produced with the $0 i 1$ and (2) it increases the energy drive in the oil zones so that more oil is swept to the production wells.

The production of several hundred gallons per minute of thermal water could upset the delicate balance between production and injection currently underway in the field. To prevent this disruption and to maintain reservoir pressure in the zones that produce thermal water, the spent thermal water (or 
waters of equivalent chemical character) would have to be injected somewhere back into these zones. Because the spent water would be of relatively low temperature, the injection of it could cause eventual cooling of the zones because the natural heat flow may be insufficient to match the turnover rates of production and injection.

Drilling and Operation of Wells

Before wells can be drilled on the naval base, it must be established who has the subsurface legal rights to undertake such a project. Drilling is a major expense; the cost rises exponentially as the depth increases. In 1979, it cost upwards of a million dollars to drill one geothermal well 5,000-6,000 feet deep (Kunze and others, 1979). It is possible that more than one production well would be needed and certainly one injection well would be necessary. Then there are expenses of completion, operation, and maintenance of the wells. The latter will be expensive because of the poor chemical quality of the water, which causes scaling and corrosion in the wells. More importantly, the cost of pumping must be weighed against the value of the heat in the produced water. Finally, performance of both wells and reservoir must be faithfully monitored to properly sustain the life of the reservoir and to document interference with adjacent production of $0 i 1$.

Perhaps drilling could be bypassed or reduced in scope if existing oil wells were converted to geothermal wells. This would involve deepening of an existing well and/or shutting off certain zones and perforating others. If permeabilities are adequate, downhole pumps could produce the volumes of thermal water necessary to make such a conversion worthwhile. So that zone temperatures aren't irretrievably cooled by the required injection, $a$ rotational system of production-injection in different wells and zones could be established. This system would allow produced zones to return to their original temperatures so that they could again take their turn in production.

EXTRACTION OF HEAT FROM OILFIELD OPERATIONS

A much simpler and less expensive method of using the geothermal energy present beneath the naval base is to extract heat from surface operations associated with oil production on and adjacent to the base. As discussed earlier, the oil wells overall produce large quantities of thermal water and oil, which are sent to central facilities for processing and disposal. Although the temperatures are lower than those that could be obtained from deep wells drilled strictly to produce thermal water, the expenses of drilling, production, and disposal are already accomplished. In addition, the large quantities of water processed at the central facilities offset somewhat the disadvantage of the water's relatively low temperature. Several considerations related to such extraction of heat are discussed below. For more detail on some of these considerations, the reader is referred to Higgins (1981).

Wells Versus Central Facilities as Sources of Heat

Certain individual production wells are the sources of the highest-temperature water in the oilfield operations adjacent to the naval base. This advantage of high temperature is diminished by the relatively small rate of production from each well. Furthermore, production wells 
commonly have down time for maintenance and eventually have to be redrilled or abandoned before the field itself is abandoned.

The injection wells generally have flow rates about 2-3 times the average flow rates of the production wells, but their temperatures are lower than the highest-temperature production wells and are no higher than that of the injection facility from which the fluids came. The wells are also subject to maintenance schedules and periodic inactivity.

In contrast to the wells, the central facilities operate continuousiy and process enormous quantities of water. The temperature of the water is relatively stable through time:. Both the "Island" and "Pier E" injection plants are well-situated for possible applications on the naval base. The "Island" plant is about 200 meters from the nearest boundary of the base, while the "Pier E" plant is on the base. The former is much superior to the latter as a source of thermal energy because of its large volumes of water. Temperatures in both are relatively low, however. The "XY" facility is much less favorably situated mainly because it: is across a shipping channel.

Effects of Extraction of Heat on 0ilfield Operations

There are two main considerations on how the extraction of heat may affect the oilfield operations. One is chemical equilibria throughout the operations, the other is efficiency of recovery of $0 i 1$.

Because of the high sal inity of the produced waters, there are constant problems of both corrosion and scaling in wells and surface facilities and plugging of sedimentary formations used for injection. These problems can and have been alleviated by appropriate treatment of the waters. Two important variables in this control of chemical equilibrium throughout the oil system and reservoir are temperature and pressure. The decrease of a water's temperature from $120^{\circ} \mathrm{F}$ to $100^{\circ} \mathrm{F}$ probably would have little effect on the equilibrium of the system, but a decrease to ambient air temperature $\left(64^{\circ} \mathrm{F}\right)$ may have some effect, the extent of which is unknown because of lack of study. Scaling of calcium carbonate and calcium sulfate are the main concerns, but the former appears to be more affected by variations in pressure rather than in temperature. Also, calcium carbonate becomes more soluble as temperature decreases. "Calcium sulfate, on the other hand, reaches a peak solubility at about $95^{\circ}$. F in pure water and becomes less soluble as temperature increases or decreases from this peak (Patton, 1977); in saline water, this temperature of maximum solubility probably varies.

The retention of heat in an oilfield system may be beneficial to the efficiency of that system. For example, higher temperatures reduce the viscosity of $0 i l$ and increase mobilization of oil through the reservoir. Heat is particularly important where the oil is highly viscous (low gravity). Such is the case in the Tar and Ranger zones of the Wilmington 0il Field. Consequently, LBOD and Champlin Petroleum try to retain as much natural heat in the oil zones and surface facilities as possible. Another method used to increase mobilization of the oil is the addition of chemicals to the system.

Transfer of Heat

The poor chemical quality of the water produced from the oil leases would require the use of heat exchangers rather than direct circulation of the water 
to its intended use. The heat would have to be transferred to a "clean" liquid in a secondary loop system tied to the end use of the heat. Although Terminal Island is heavily industrialized, the "Island" and "Pier E" facilities probably have sufficient space for such a heat-exchanger system. The length of pipeline from the heat-exchanger system to the site of intended use of the heat must be as short as possible because the costs of insulated pipe, its placement, and pumping of the liquid within it are expensive; many geothermal projects are abandoned not because the resource is insufficient but because the cost of the transport system to the application is uneconomical. If the heat transferred to the secondary liquid is inadequate for uses at the naval base, the temperature could be boosted by use of some other fuel. The owner of the heat in the oilfield system and regulation of the heat's cost and use are legal and economic questions that would have to be resolved among the Department of the Navy, the oil companies, and any state or local governmental agencies or private parties with legal rights in the local area.

\section{Longevity of oilfield Operations}

The value of the oilfield operations as sources of thermal energy for the naval base is dependent on the life expectancy of the Wilmington 0il Field. Although fault block III is considered the weakest producer in this part of the field, operators expect the entire field to be functional through at least the year 2000. When the field is eventually. depleted of oil, the prevailing economics may be favorable enough so that some wells and central facilities adjacent to the naval base could be converted to production of thermal water for use on the base. This conversion must be planned years in advance, however,: so that wells and surface facilities are not allowed to deteriorate beyond economic maintenance or high quality of performance. 
PHYSICAL SETTING

The Seal Beach Naval Weapons Station covers several square kilometers of flat, mostly undeveloped land east of the downtown area of the city of Seal Beach (Figure 1, Plate 2). It is surrounded by residential and commercial development. The main function of the weapons station is the storage and supply of ammunition for warships, which dock in Anaheim Bay at the station's southwest edge. All the naval base's main buildings are in a narrow corridor along the west side of the base (Plate 2). Much of the southwestern part of the weapons station is a tidal swamp formally designated a national wildlife refuge. The southeasternmost portion of the Seal Beach 0il Field also underlies this area.

\section{SUBSURFACE GEOLOGY}

Except for the Upper Pleistocene sediments that comprise Landing Hill along its west boundary, the weapons station is covered by Quaternary alluvium (Figure 7). Consequently, information on the geology beneath the naval base has been derived almost entirely from geophysical exploration and the drilling of oil and water wells. Unlike the Long Beach naval base, oilfield development has affected only a small portion of the weapons station; therefore, most of the subsurface geology is poorly known.

\section{Stratigraphy}

The stratigraphy beneath the weapons station is similar in general to that at the Long Beach naval base (Figure 8). Granitic and schistose rocks comprise the basement, which is overlain by mostly alternating sandstones and shales of predominantly Tertiary age; under the nor theastern part of the naval base, Cretaceous (?) sedimentary rocks underlie the Tertiary rocks. Altogether, the sedimentary rocks beneath the weapons station are about twice as thick. as those at the Long Beach naval base. The Puente and Repetto Formations are the thickest units and produce all the oil in the Seal Beach oil Field. The various oil-producing zones in the field are labeled in Figure 8.

The minimum depth to basement beneath the weapons station is estimated to be at least 12,000 feet, under Anaheim Bay (Figure 9). Only one well, Conoco's Bixby A No. 62, is known to have penetrated either to or very near the top of basement in the area. This well was drilled to 12,162 feet northwest of the weapons station, just west of the Newport-Inglewood fault zone (Figure 9). The greatest depth to basement is expected beneath the nor thernmost part of the weapons station at about 20,000-22,000 feet.

Structure

The general structure beneath the weapons station includes three main features. From west to east, these are: the easternmost extension of the Torrance-Wilmington anticline, the Newport-Inglewood fault zone, and the southwest limb of the Downey syncline. 


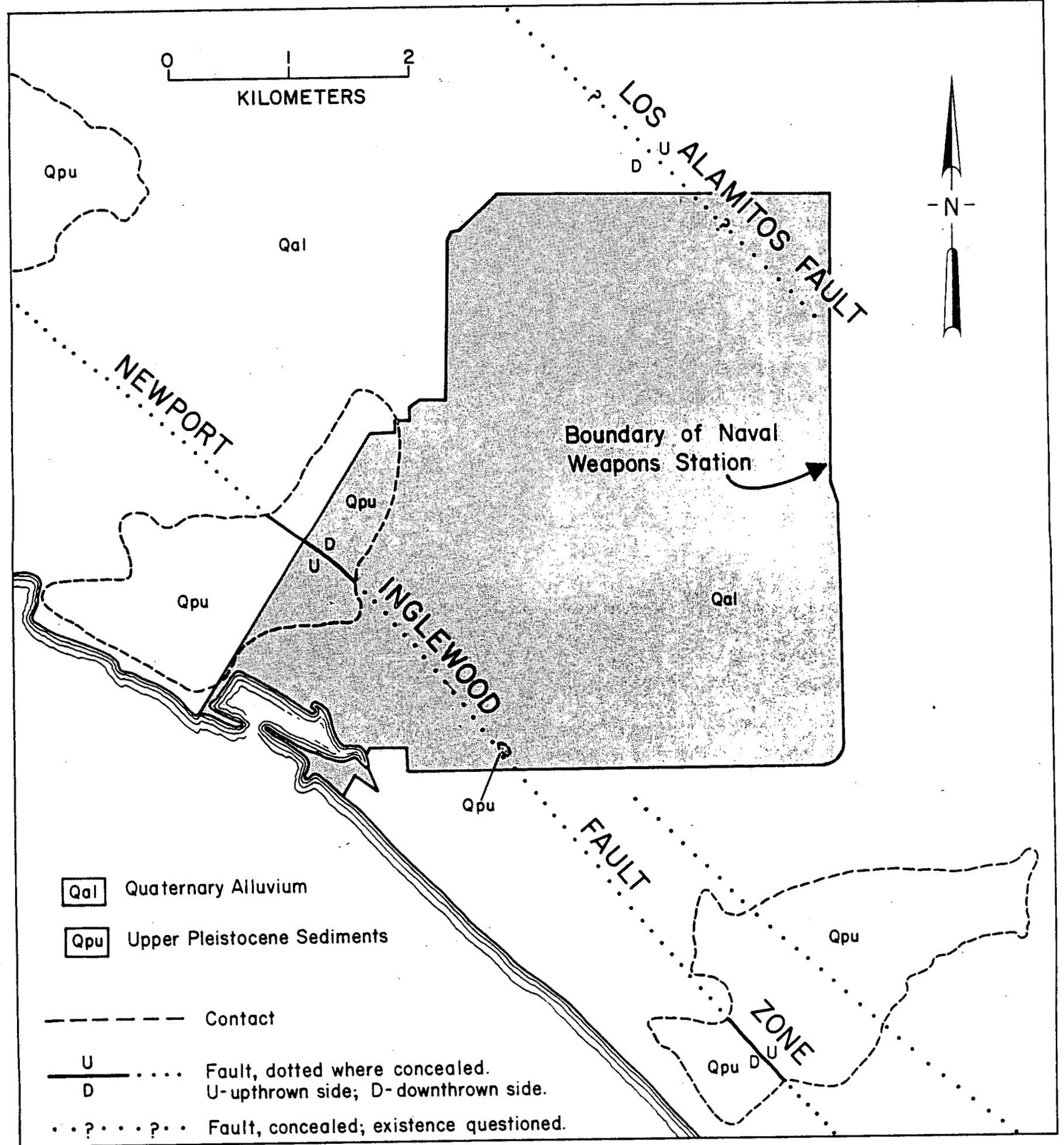

FIGURE 7 - Generalized geologic map of the area including the Seal Beach Naval Weapons Station. Geologic data were modified from Poland and others $(1956)$. 


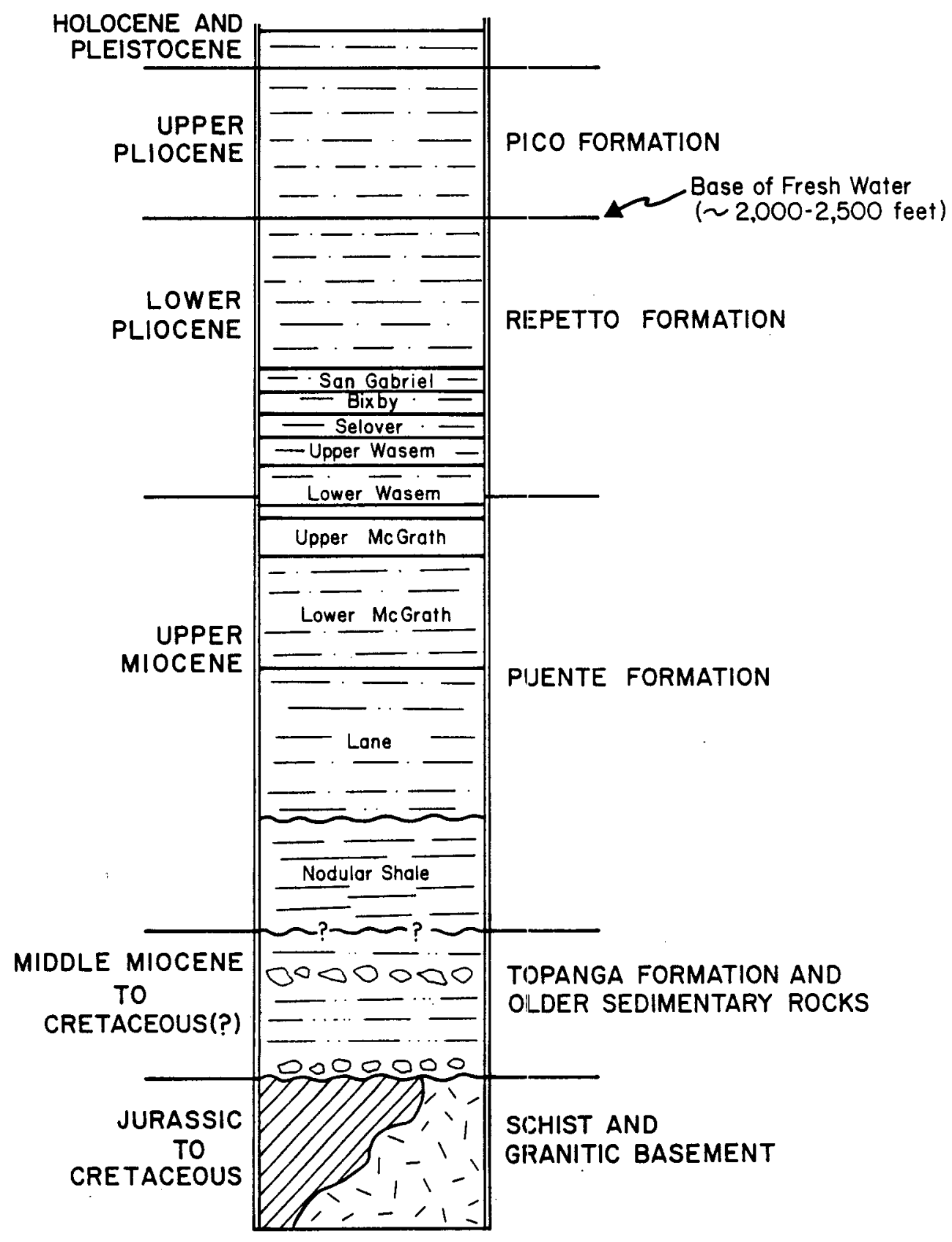

FIGURE 8 - Generalized stratigraphy beneath the Seal Beach Naval Weapons Station. Names within the column are production zones of the Seal Beach $0 i 1$ Field. The stratigraphy was modified from Ingram (1966), Yerkes and others (1965), and the California Division of $0 i l$ and Gas (1974). 


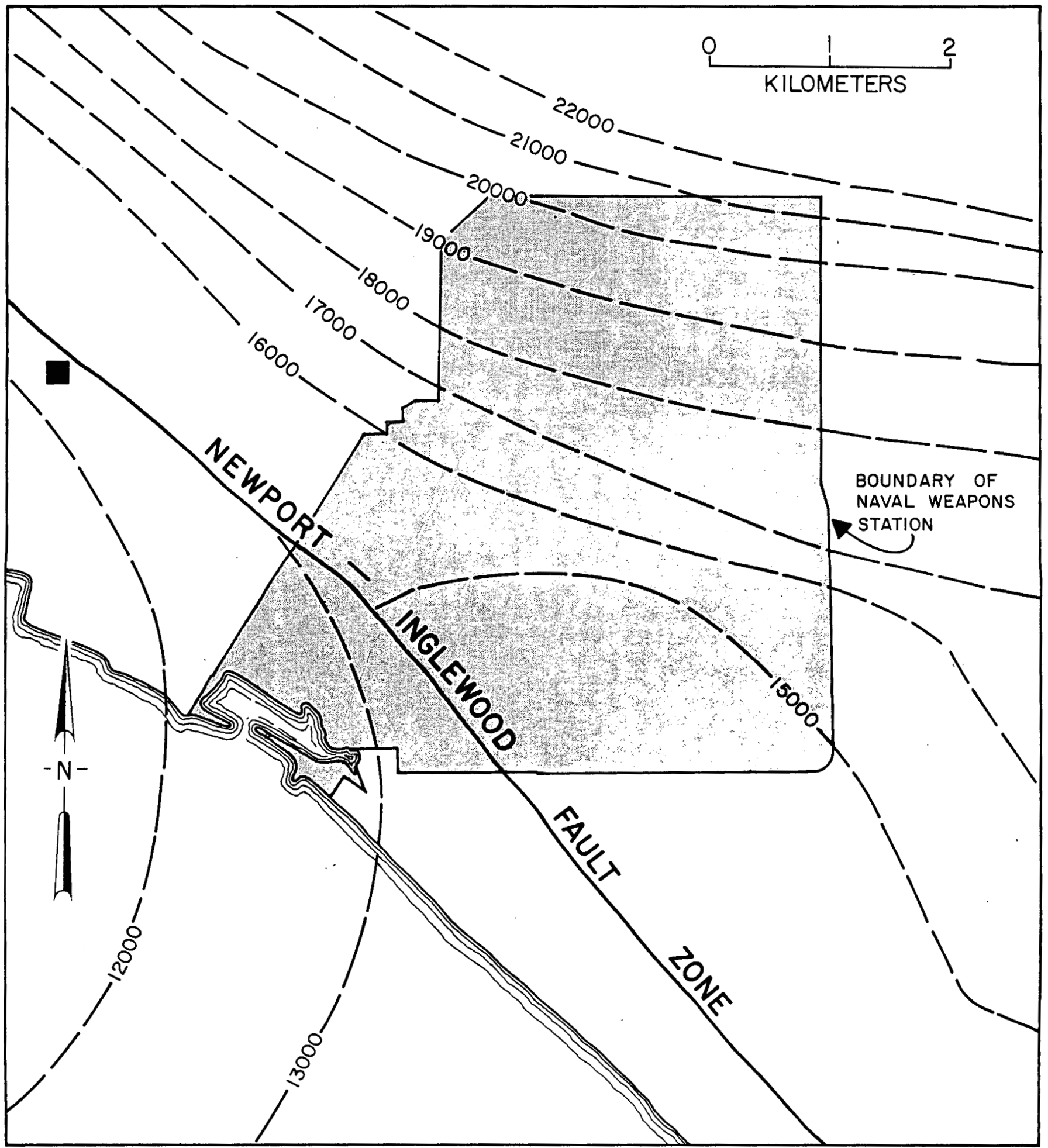

FIGURE 9 - Estimated depth to basement in the vicinity of the Seal Beach Naval Weapons Station. Contours are in feet below mean sea level and are modified from Yerkes and others (1965). The square is the location of Conoco's "Bixby A" No. 62 well. The naval weapons station is shaded. 
The dominant structure under most of the weapons station is the north-northeast-dipping limb of the Downey syncline. Under the southwest part of the weapons station, the limb is interrupted by the steeply-dipping to vertical Newport-Inglewood fault zone (Figures 7,9 ). Although movement along the zone is dominantly right-lateral, there appears to be some dip-slip motion in places. The zone comprises several splays in addition to some cross faults (Figure 7, Plate 2) and is associated with a regional anticline along its strike (Poland and others, 1956). Offshore of and beneath the southwesternmost part of the weapons station is the flank of the TorranceWilmington anticline. The anticline probably either flattens against or is truncated by the Newport-Inglewood fault zone.

Detailed structure beneath the weapons station is mostly unknown because of scarce subsurface exploration. Certainly the three regional structures have small aberrations, a few of which are known locally. Some of these local structures are described briefly here and amplified upon where appropriate in a subsequent discussion of geophysical investigations by the Division of Mines and Geology. The first two structures discussed are uplifts within the Newport-Inglewood fault zone, which is characterized by domes and anticlines along its entire length in the Los Angeles basin (Poland and others, 1956).

The Seal Beach 0il Field is astride the Newport-Inglewood fault zone and is developed within an elongated dome, termed the Seal Beach dome (Bowes, 1943). The dome is expressed in the surface topography by Landing Hill along the western boundary of the weapons station, and Los Alamitos Heights, farther northwest (Plate 2). It is cut longitudinaily near its axis by the Newport-Inglewood fault zone.

Just southeast of the Seal Beach dome, beneath the weapons station, is a small anticline, which is also truncated by splays of the Newport-Inglewood fault zone. This structure produces oil as part of the Seal Beach 0 il Field and is designated the "North Block-East Extension" (Ingrams, 1966). Contours on top of one of the producing zones are shown on Plate 2.

Beneath the northeast corner of the weapons station is a speculative structure termed the Los Alamitos fault (Figure 7). Its presence is tentatively based on logs of water wells, but it is not clear if the structure is a fault or fold (California Department of Water Resources, 1961, 1967).

Geophysical Investigations

The Division's geophysical investigations of the Seal Beach Naval Weapons Station consisted of analyses of published regional gravity and magnetic maps of the area and performance and interpretation of a detailed gravity survey of the weapons station and adjacent: areas. - The gravity survey was performed because it is generally the best technique for study of geologic structure. Details of the field procedure and data-reduction for the gravity survey are described in Appendix A.

The weapons station and surrounding area are included in a regional gravity map (Beyer and Biehler, 1982) and an aeromagnetic map (Andreason and others, 1964). The aeromagnetic map was of 1 imited usefulness because most of the magnetic anomalies appear to be caused by concentrations of oil wells and other cultural features. The Division did not make ground magnetic measurements in the area because the numerous cultural features interfere with 
measurements of the magnetic field. The Division also did not conduct any electrical resistivity or similar surveys.

The purpose of the gravity survey was to improve our knowledge of known structures beneath the naval base and to discover structures that might be sites of fluids with temperatures higher than those of the surrounding subsurface. In this region, such sites could be open fault zones with access to deeply-circulating hot fiuids or basement highs (typically domes or anticlines) that have relatively high geothermal gradients. Both the fault zones and basement highs can cause gravity anomalies.

Gravity Data and Its Interpretation:

Plate 3 is the Bouguer gravity map of the area contoured at an interval of one milligal (mgal). This map includes the gravity data obtained during this study as well as all of the gravity data available from published surveys in the area.

The most prominent feature of the gravity field shown on plate 3 is a regional trend that dips steeply to the northeast. This trend is also shown on the gravity map of Beyer and Biehler (1982). In the map area, the gravity gradient is about $7 \mathrm{mgal}$ per mile (4 mgal per $\mathrm{km}$ ). This gradient probabiy reflects both the increasing thickness of the crustal rocks inland from the margin of the continent and the increasing depth of the basement rocks in the direction of the Downey syncline, whose axis is nor theast of the map area.

Local anomalies are difficult to distinguish on Plate 3 because of the steep gravity gradient. For this reason, residual gravity maps were prepared for the area both by means of a polynomial trend-surface program and by manual construction of a smooth regional gravity surface from profiles that cross the area. Of several trend-surface residual maps prepared, the second order residual map was similar to the profile residual map and thus corroborated the latter. Plate 4 is the profile residual map of the Seal Beach area with a contour interval of $0.2 \mathrm{mgal}$.

The most prominent feature of the residual map is a northwest-trending positive anomaly that crosses the weapons station from the vicinity of Landing Hill on the nor thwest to near Hog I sland and beyond on the southeast. The maximum amplitude of this anomaly is about $0.8 \mathrm{mgal}$, between $\mathrm{Kitt}$ Avenue and Bay (now Seal Beach) Boulevard. Northwest of Landing Hill, the amplitude increases slightly, but southeast of Kitt Avenue, it decreases. Near the southern boundary of the weapons station, and to the southeast, the amplitude of the anomaly again increases slightly (shown by $+0.2 \mathrm{mgal}$ contours).

The northwest-trending positive residual anomaly may represent the approximate location of the crest of the regional anticline associated with the Newport-Inglewood fault zone. Plate 4 shows that there is indeed a close association between the mapped fault traces and the residual anomaly.

The relatively large positive anomaly associated with Landing $\mathrm{Hill}$ may represent part of the Seal Beach dome. Southeast of this dome, there is probably a saddle in the regional anticline, which corresponds to the decrease in amplitude of the anomaly in this area (California Department of Water Resources, 1968, Plate 3A). The truncated anticline of the North Block-East 
Extension does not appear as a closure of contours on Plate 4 , perhaps because of a lack of detailed gravity data in this area. The slight increase in the amplitude near the southern boundary of the weapons station may represent the Sunset Beach dome associated with Sunset Beach 0il Field. The small positive anomaly in the extreme southeastern part of the map area, near the East Garden Grove Channel, probably represents the northwestern part of the Huntington Beach anticline (Cal ifornia Department of Water Resources, 1968, p. 34).

Figure 10 is a residual gravity profile ( $\left.A-A^{\prime}\right)$ along a nor theast-trending line (Kitt Avenue) in the western part of the weapons station. The positive anomaly over the Seal Beach dome has a maximum amplitude of about $0.8 \mathrm{mgal}$ on the profile. Also shown on Figure 10 are the location of the Newport-Inglewood fault zone and two possible models of anticlines that could explain the gravity anomaly. These models illustrate the general shape of the geologic structure needed to explain the observed anomaly. In general, the anomaly could be caused by a relatively large structure close to the surface with a small positive density contrast, or by a smaller structure at depth with a higher density contrast. A combination of these and other models is also possible. There is insufficient information available, particularly in regard to density contrasts, to narrow the range of possible models.

Additional small residual gravity ancmalies with amplitudes of a few tenths of a milligal include a small northeast-trending positive anomaly in the northwestern corner of the weapons station and a negative anomaly just east of the weapons station. The causes of these small anomalies are not known, but they are probably associated with variations in the sedimentary rocks. There is no apparent gravity expression of the nor thwest-trending Los Alamitos fault.

Geothermal Gradient

The geothermal gradient beneath the weapons station is less well-known than that at the Long Beach naval base. No temperature gradient survey is known to have been conducted in this area.

Figure 11 is an estimated curve of geothermal gradient for the southwest part of the weapons station in the vicinity of the Newport-Inglewood fault zone. Tied to a mean annual air temperature of $64^{\circ} \mathrm{F}$, bottom-hole temperatures recorded in several dozen oil wells and exploratory holes were the main data used to construct the curve. The straight line of the gradient curve was drawn as an upper boundary to envelop all the reported temperatures. The reasoning for this is that, at depths greater than a few thousand feet, the temperatures measured in the holes are almost always lower than the true temperature at that depth; this discrepancy is because the holes are not allowed sufficient time to return to equilibrium temperature before the temperature is measured. Unpublished zone temperatures reported by the California Department of Conservation, Division of $0 i 1$ and Gas for the Seal Beach oil Field plot somewhat favorabiy about the curve, but, by themselves, were too scattered and inconsistently determined by different methods to use to construct the curve.

The computed gradient of about $2.2^{\circ} \mathrm{F} / 100$ feet $\left(4.0^{\circ} \mathrm{C} / 100\right.$ meters $)$ is above "normal" but substantially less than that at the Long Beach naval base. It is probably lower because of the greater depth to basement here even though the 


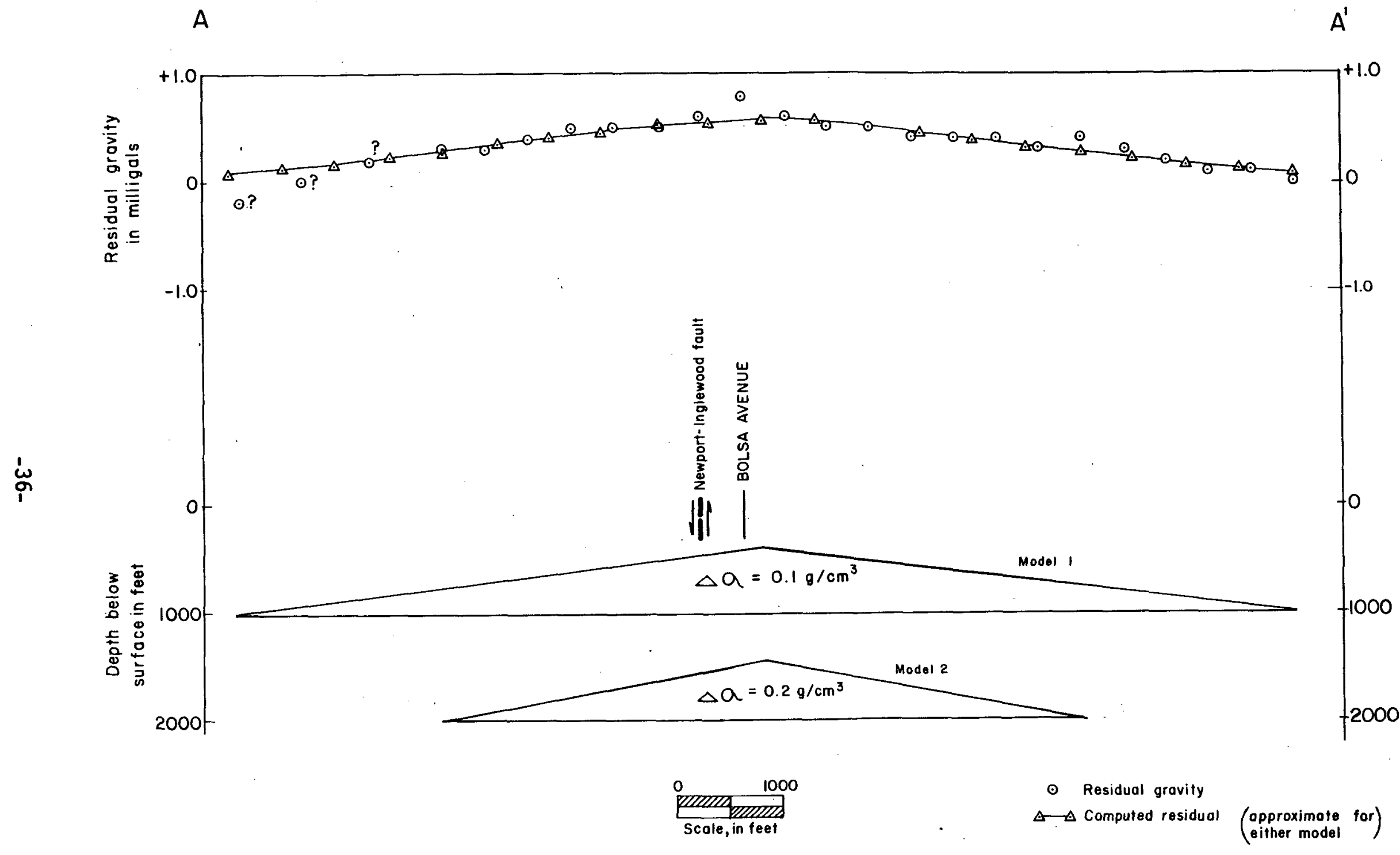

FIGURE 10 - Residual gravity profile $A-A^{\prime}$ and its interpretation. The profile is along Kitt Avenue, Seal Beach Naval Weapons Station. 


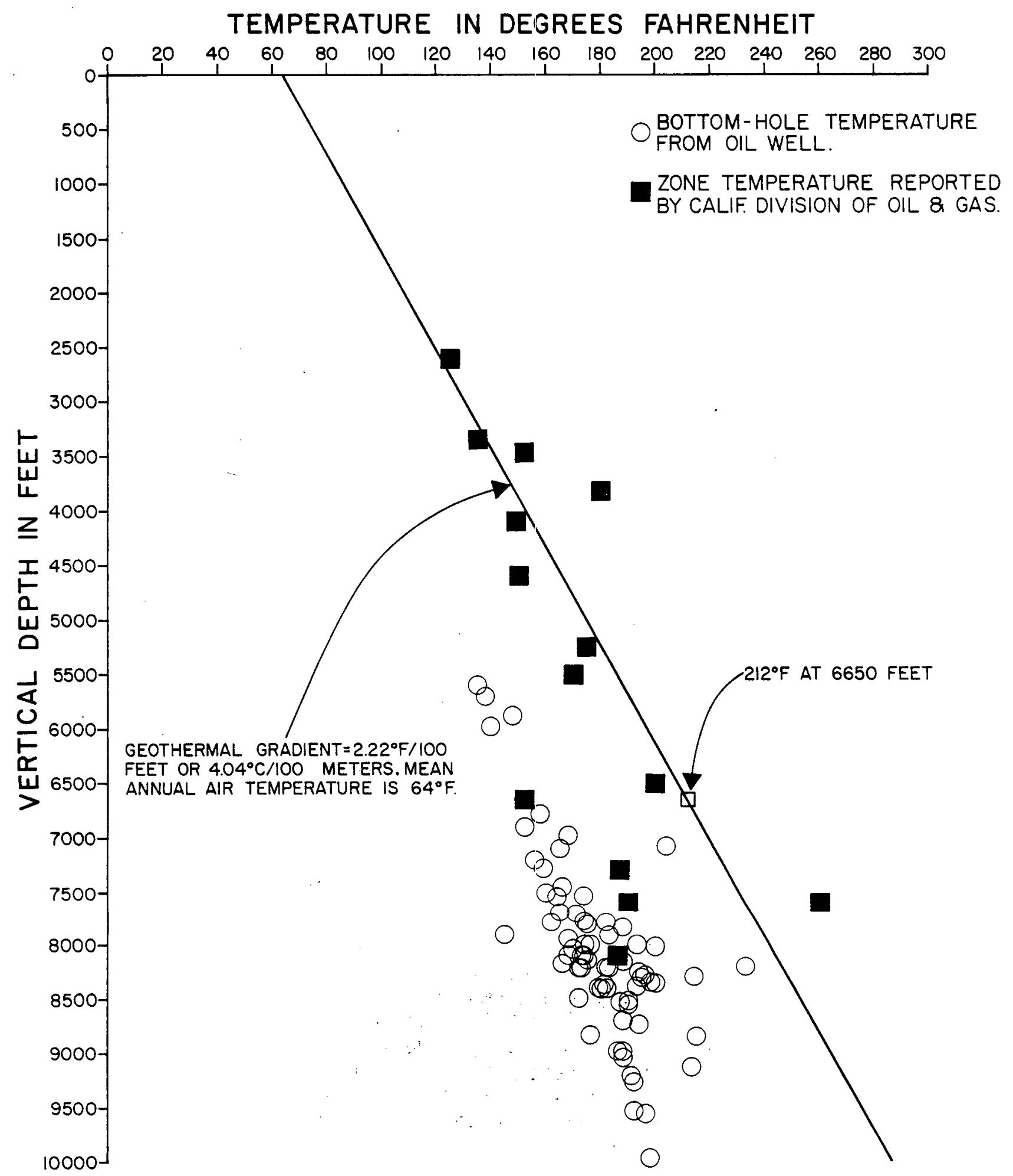

FIGURE 11 - Curve of estimated geothermal gradient beneath the southwest part of the Seal Beach Naval Weapons Station. The bottom-hole temperatures were obtained from unpublished records of the California Division of 0il and Gas. 
thermal conductivities of the sedimentary rocks at the two bases are probabily very similar. The effect of higher thermal conductivity of the basement on the geothermal gradient in the uppermost 10,000 feet of overlying sediments is diminished by the basement's great depth.

Using Figure 11 , a temperature of $212^{\circ} \mathrm{F}$ (boiling point of water at sea leve1) is expected at a depth of $6,600-6,700$ feet beneath the southwest part of the weapons station. Temperatures at the contact between the basement and overlying sedimentary rocks in this area are expected to exceed $300^{\circ} \mathrm{F}$.

It is probable that the geothermal gradient progressively decreases away from this area toward the northeast edge of the naval base, which would result in successively lower temperatures for a given depth. This expected decrease is caused by the greater depth to basement as discussed earlier.

PHYSICAL AND CHEMICAL PROPERTIES OF THE ROCK UNITS

Shallow (Fresh-Water) Sediments

The weapons station is underlain by extensive fresh-water-bearing sediments including many large aquifers. Permeabilities of the aquifers generally decrease with depth and range from moderate to high. Morel and and Singer (1969) reported permeabilities as high as $2,500 \mathrm{gal}$ per day/ft2 $(1.22$ $\left.\times 10^{5} \mathrm{md}\right)$ in Holocene sediments to 50-300 gal per day/ $\mathrm{ft}^{2}(2.44 \mathrm{x}$ $10^{3}--14.65 \times 10^{3} \mathrm{md}$ ) in the Pico Formation.

The approximate base of fresh water is generally thought to be the contact of the Pico Formation with the Repetto Formation. This contact dips nor theast as part of the Downey syncline; both formations thicken in this direction also. Depth to the contact probably ranges from about 1,700 feet in the southwest to over 3,000 feet beneath the north edge of the naval base.

Plate 2 displays contours on what is termed by the California Department of Water Resources (1967) the "effective base of the ground water reservoir." This base was defined as the lower limit above which at least $25 \%$ of the vertical sedimentary section must contain permeable sediments capable of yielding 50 or more gal/minute of fresh water to wells. In general, this base is shallower than the lower contact of the Pico Formation.

Many water wells have been drilled on the weapons station over the years, but most are abandoned. Temperatures measured on several of these wells (Plate 2) do not indicate that any are anomalously thermal; well-head temperatures reported in records of the California Department of Water Resources (1980) ranged from $61^{\circ}$ to $81^{\circ} \mathrm{F}$. The wells measured ranged in depth from several hundred to over 1,000 feet, thus the temperatures do not represent an anomalously high gradient. Fresh water produced from these wells is typically sodium-calcium bicarbonate in chemical type and has total dissolved solids of about $250 \mathrm{ppm}$.

Based on the gradient of Figure 11, temperatures expected at the effective base of the ground water reservoir beneath the southwestern part of the weapons station are about $70^{\circ}-80^{\circ} \mathrm{F}$. Beneath the nor theast part of the station, where the effective base is deepest (about 2,000 feet), temperatures may be approximately $100^{\circ}-110^{\circ} \mathrm{F}$. 
Below the Pico Formation, the sedimentary rocks are mostly alternating marine sandstones and shales that contain saline waters. $0 i 1$ is produced from zones in the lowest part of the Repetto Formation and in the Puente Formation (Figure 8). Most 011 in the area of the weapons station is produced from the Wasem and MCGrath zones at about 5,000-8,000 feet depth.

Average reservoir properties for the six main oil-producing zones of the Seal Beach 0il Field are presented in Table 5. Properties of the upper, non-producing part of the Repetto Formation are expected to be intermediate between those of the San Gabriel-Bixby zones and the lower part of the Pico Formation. Specific properties of the sedimentary rocks below the Lane zone are largely unknown.

In the oil-producing zones, sandstones and shales are present in approximately equal amounts. Original reservoir pressures increased with depth, but some have since been reduced because of oil production. Porosities decrease with depth as expected, yet permeabilities appear to be highest in the Selover and Upper Wasem zones; figures of over 1,200 md have been recorded in the latter. Never theless, permeabilities overall are low to moderate with the lowest in the McGrath and Lane zones. Sedimentary rocks below the latter two zones, especially the Middle Miocene to Cretaceous(?) rocks, are expected to have very low permeabilities because of consolidation by deep burial.

Total dissolved solids in water of the oil-producing zones range from about 20,000 to $31,000 \mathrm{ppm}$. The water in all zones is of the sodium chioride type with a slightly basic pH. Representative chemical analyses of the upper oil-producing zones are presented in Table 6.

Basement

The schistose and granitic rocks beneath the weapons station are probably an effective lower limit to the downward movement of ground water from overlying sedimentary formations. By nature, the basement is largely impermeable except perhaps where open fractures allow the deep penetration of ground water, which would heat the water and perhaps cause it to ascend along other open fractures. The volume of water present in such fractures is thought to be very sma11, however, compared to the volume of static water in the overlying sedimentary rocks.

OILFIELD OPERATIONS

Along the Newport-Inglewood fault zone on and adjacent to the Seal Beach Naval Weapons Station, there has been extensive development of oil fields, mainly during the early and middle part of this century (Figure 12). The main part of the Seal Beach 0il Field is northwest of the naval base with a small extension (North Block-East Extension) beneath the base. The much smaller Sunset Beach 0il Field in entirely off the weapons station to the southeast. A few exploratory holes were drilled on and adjacent to the naval base, outside of these fields (Plate 2), but no commercial quantities of oil were found to warrant development. 
TABLE 5 - Physical and chemical properties of oil-producing zones in the Seal Beach 0il Field, as modified from unpublished records of the California Division of $0 i 1$ and Gas.

\begin{tabular}{|c|c|c|c|c|c|c|c|c|c|}
\hline ZONE & $\begin{array}{l}\text { SHALLOWEST DEPTH } \\
\text { TO TOP OF ZONE* } \\
\text { (Feet) }\end{array}$ & $\begin{array}{c}\text { AVERAGE } \\
\text { TEMPERATURE } \\
\left({ }^{\circ} \mathrm{F}\right)\end{array}$ & $\begin{array}{l}\text { AVERAGE } \\
\text { THICKNESS } \\
\text { (Feet) }\end{array}$ & $\begin{array}{l}\text { APPROXIMATE } \\
\text { AVERAGE } \\
\% \text { SAND }\end{array}$ & $\begin{array}{l}\text { INITIAL. RESERVOIR } \\
\text { PRESSURE } \\
\text { (psi) }\end{array}$ & $\begin{array}{l}\text { AVERAGE } \\
\text { POROSITY } \\
(\%)\end{array}$ & $\begin{array}{l}\text { AVERAGE } \\
\text { PERMEABILITY } \\
(M d)\end{array}$ & $\begin{array}{c}\text { GRAVITY OF } \\
\text { OIL } \\
\left({ }^{\circ} \mathrm{API}\right)\end{array}$ & $\begin{array}{c}\text { TOS IN } \\
\text { WATER } \\
(\mathrm{ppm})\end{array}$ \\
\hline San Gabriel & 5250 & 180 & 150 & $25-30$ & 1850 & 34 & $?$ & $20-27$ & 31,600 \\
\hline Bixby & 5400 & 184 & 200 & 70. & $1500-2000$ & $28-37$ & 200 & $21-25$ & 31,000 \\
\hline Selover & 5600 & 188 & 200 & 60 & $1600-2100$ & $29-30$ & $400-600$ & $24-28$ & $26,600-27,400$ \\
\hline Wasem & 5800 & 193 & 700 & 60 & $2150-2400$ & $24-28$ & $125-1281$ & $20-28$ & $25,700-31,000$ \\
\hline McGrath & 6700 & 213 & 1500 & 40 & $2800-3215$ & $21-24$ & $50-150$ & $25-34$ & $20,000-26,000$ \\
\hline Lane & 8200 & 246 & 2000 & 50 & $3400-3760$ & $16-18$ & 20 & $28-32$ & 31,000 \\
\hline
\end{tabular}

* Beneath Seal Beach Naval Weapons Station only. 
TABLE 6 - Chemistry of waters produced from selected zones in the Seal Beach 0il Field, as modified from unpublished records of the California Division of $0 i 1$ and Gas.

\begin{tabular}{|c|c|c|c|c|c|c|c|c|c|c|c|c|c|c|c|c|}
\hline ZONE & DATE & $\mathrm{pH}$ & $\mathrm{Na}$ & $\mathrm{NH}_{4}$ & $\mathrm{Ca}$ & $\mathrm{Mg}$ & $\mathrm{Ba}$ & $\mathrm{Fe}$ & $\mathrm{SO}_{4}$ & $\mathrm{Cl}$ & $\mathrm{HCO}_{3}$ & $\mathrm{CO}_{3}$ & $\mathrm{~B}_{4} \mathrm{O}_{7}$ & I & $\mathrm{SiO}_{2}$ & TDS \\
\hline $\begin{array}{l}\text { San Gabriel } \\
\text { and Bixby }\end{array}$ & $1 / 8 / 73$ & 7.3 & 11,015 & 115 & 560 & 310 & 98 & 8 & $T$ & 18,865 & 335 & 0 & 155 & 105 & 50 & 31,645 \\
\hline Selover & 1977 & 7.9 & 9,110 & 105 & 330 & 100 & 48 & 26 & 22 & 14,000 & 1,755 & 0 & 240 & 40 & 50 & 26,600 \\
\hline
\end{tabular}




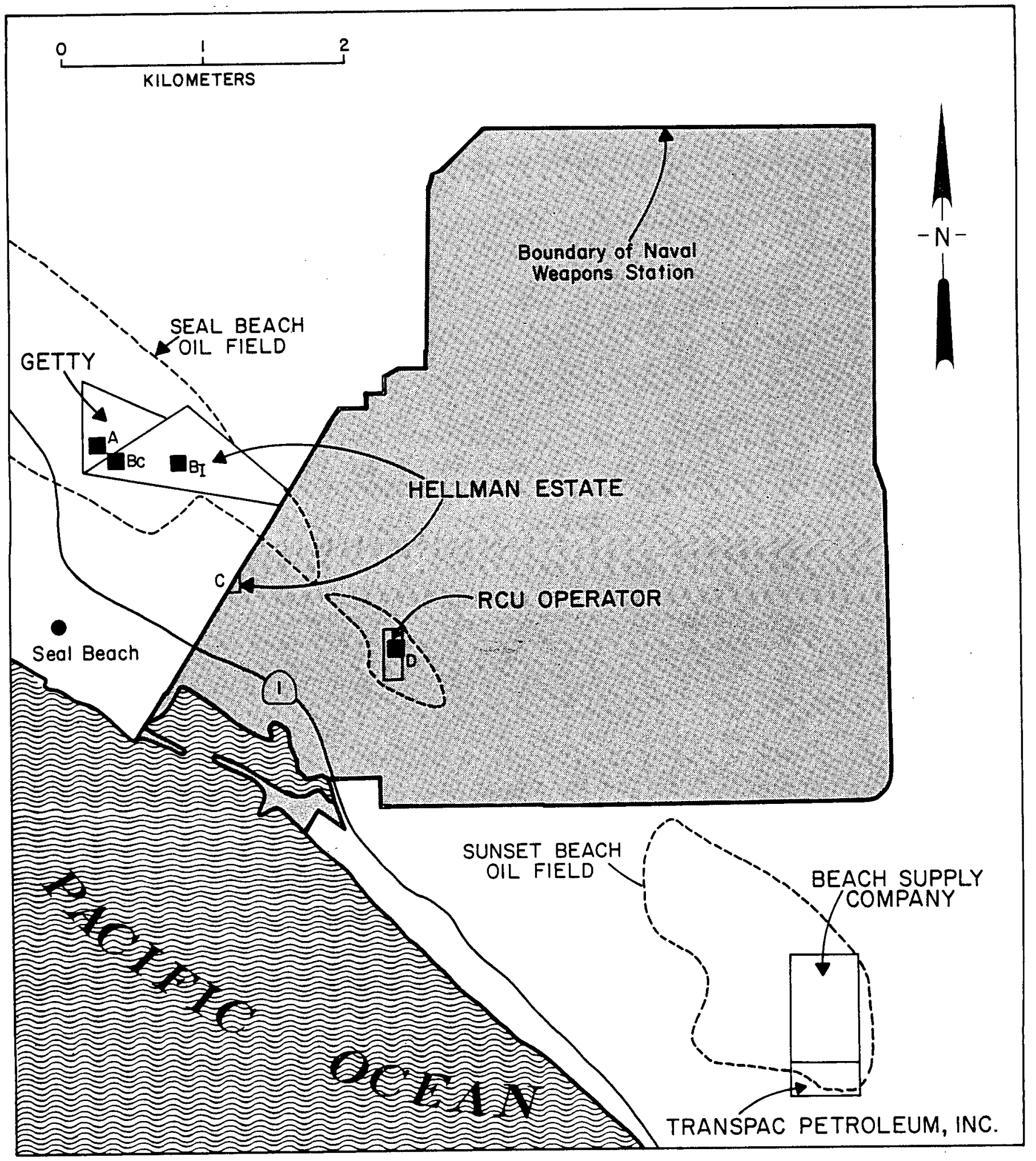

FIGURE 12 - Locations of oil field leases and central processing facilities on or adjacent to the Seal Beach Naval Weapons Station. Names of operators are shown on the leases. Facilities are as follows: A - "Bryant" lease. collection and injection unit, $B_{C}$ - "Hellman Estate" lease collection unit, BI - "Hellman Estate" lease injection unit, C - "City of Seal Beach" lease storage tanks, D - "Alamitos" lease collection and injection unit. The naval weapons station is shaded. 
As at Wilmington oil Field, these two fields produce hot oil and water from depths of several thousand feet. The fluid is piped to central processing facilities in the Seal Beach oil Fjeld and to tanks at the individual well sites in the Sunset Beach 0 il Field.

Production and Injection/Disposal Wells*

Within the wildlife refuge on the weapons station is RCU Operator's "Alamitos" lease, which is developed in the North Block-East Extension. A small cluster of about 2 dozen wells here are slant-drilled to the nor thwest and southeast into the McGrath and Wasem zones, which range from about 5,000 to 8,000 feet deep. Well-head temperatures, measured in November 1983, and rates of production for each of the production wells on the lease are presented in Table 7 . The temperatures ranged from $84^{\circ}$ to $163^{\circ} \mathrm{F}$, while the rates of production ranged from 1 to $9 \mathrm{gal} /$ minute. All wells, except numbers 14 and 18 , produce from about 8,000 feet deep. A crude correlation between temperature and rate of production is also apparent in Table 7.

Only a small portion of the main Seal Beach 0 il Field is present beneath the naval base. The only leases that produce from this portion are operated by Hellman Estate along the base's west boundary. One, the "Hellman Estate" lease, has several dozen production wel1s about 16 of which are slant-drilled under the base. Well-head temperatures of most of these 16 were measured in November 1983 and ranged from $81^{\circ}$. to $127^{\circ} \mathrm{F}$ with all but four less than $100^{\circ} \mathrm{F}$ (Table 8 ). Rates of production ranged from less than 1 gal/minute to 4 gal/minute with most less than 2 gal/minute. The "City of Seal Beach" lease has two wells, which together produce onily a few gallons of $0 i 1$ and water per minute at $73_{-}^{\circ}-91^{\circ} \mathrm{F}$ (Table 8 ).

Temperatures of individual production wells on the "Bryant" lease, operated by Getty oil Company farther nor thwest, were not investigated.

Southeast of the weapons station, the Sunset Beach 0 il Field has only 5 active production wells. During 1983, one well produced about $10 \mathrm{gal} / \mathrm{minute}$ at possibly $140^{\circ} \mathrm{F}$ (because the temperature was not measured, it was estimated from both depth and rate of production). The other 4 wells produced a combined total of $3 \mathrm{gal} /$ minute at temperatures probabiy less than $100^{\circ} \mathrm{F}$.

All production wells discussed here are pumped with standard beam-rod pumping units. The percentage of water produced by individual wells ranged from as low as about $10 \%$ to over $90 \%$. As evident from Tables 7 and 8 , well-head temperatures would probably be higher than they are if rates of production were increased.

During 1983, the "Alamitos" lease had one disposal well operating at an average rate of 62 gal/minute at $113^{\circ} \mathrm{F}$. The "Hellman Estate" lease had one injection well operating at 17 gal/minute and one disposal well at 30 gal/minute. Both were injecting water at $80^{\circ} \mathrm{F}$ or less. Getty's "Bryant" lease had 2 disposal wells, each disposing of about $14 \mathrm{gal} / \mathrm{minute}$ at approximately $70^{\circ} . \mathrm{F}$. The sunset Beach $0 i 1$ Field had neither injection nor disposal of water into the subsurface.

* An injection well injects fluids into an oil-producing zone for additional recovery, while a disposal well injects fluids into a non-producing zone. 
TABLE 7 - Well-head temperatures and rates of production from oil welis on the "Alamitos" lease on the Seal Beach Naval Weapons Station. The temperatures were measured by the senior author in November 1983. The volumes are averages for the first 8 months of 1983, as reported in unpublished records of the California Division of $0 i l$ and Gas.

\begin{tabular}{cccc} 
& WELL & TEMPERATURE ( $\left.{ }^{\circ} \mathrm{F}\right)$ & VOLUME (GAL/MIN) \\
\cline { 2 - 3 } & 5 & $163^{\circ}$ & 9 \\
3 & $144^{\circ}$ & 8 \\
16 & $144^{\circ}$ & 7 \\
18 & $140^{\circ}$ & 7 (Wasem) \\
15 & $138^{\circ}$ & 8 \\
7 & $135^{\circ}$ & 5 \\
24 & $133^{\circ}$ & 5 \\
14 & $129^{\circ}$ & 5 (Wasem) \\
2 & $120^{\circ}$ & 3 \\
10 & $120^{\circ}$ & 3 \\
26 & $108^{\circ}$ & 3 \\
19 & $106^{\circ}$ & 3 \\
8 & $104^{\circ}$ & 2 \\
13 & $97^{\circ}$ & 1 \\
4 & $95^{\circ}$ & 1 \\
6 & $95^{\circ}$ & 1 \\
20 & $91^{\circ}$ & 2 \\
21 & $84^{\circ}$ & 2
\end{tabular}


TABLE 8 - Well-head temperatures and rates of production from selected oil wells on the "Hellman Estate" and "City of Seal Beach" leases adjacent to the Seal Beach Naval Weapons Station. The temperatures were measured by the senior author in November 1983. The volumes are averages for the first 8 months of 1983, as reported in unpublished records of the California Division of $0 i 1$ and Gas.

\begin{tabular}{|c|c|c|c|}
\hline & WELL & TEMPERATURE $\left({ }^{\circ} \mathrm{F}\right)$ & VOLUME (GAL/MIN) \\
\hline \multirow[t]{17}{*}{ Hel1man Estate } & 34 & $127^{\circ}$ & 4 \\
\hline & 33 & $113^{\circ}$ & 2 \\
\hline & 38 & $106^{\circ}$ & 1 \\
\hline & 51 & $100^{\circ}$ & 2 \\
\hline & 26 & $99^{\circ}$ & 1 \\
\hline & 35 & $99^{\circ}$ & 2 \\
\hline & 57 & $97^{\circ}$ & 2 \\
\hline & 58 & $97^{\circ}$ & 1 \\
\hline & 39 & $95^{\circ}$ & 1 \\
\hline & 19 & $93^{\circ}$ & 7 \\
\hline & 31 & $91^{\circ}$ & 1 \\
\hline & 55 & $88^{\circ}$ & 1 \\
\hline & 27 & $86^{\circ}$ & $<1$ \\
\hline & 52 & $84^{\circ}$ & 1 \\
\hline & 53 & $84^{\circ}$ & 1 \\
\hline & 54 & $82^{\circ}$ & $<1$ \\
\hline & 56 & $81^{\circ}$ & 1 \\
\hline \multirow[t]{2}{*}{ City of Seal Beach } & 1 & $91^{\circ}$ & 1 \\
\hline & 2 & $73^{\circ}$ & $<1$ \\
\hline
\end{tabular}


Figure 12 and Plate 2 show the locations of the central facilities for the oilfield operations on and adjacent to the weapons station. Table 9 lists the volumes, temperatures, and amounts of thermal energy at the different facilities for each of the oil leases.

of the four leases investigated in the Seal Beach 0il Field in 1983, the "Alamitos" lease had the highest temperatures and rates of production and disposal. Production from all wells (about 81 gal/minute at $122^{\circ} \mathrm{F}$ ) was sent to the lease's central tank system where about 62 gal/minute of water was separated and piped at approximately $113^{\circ} \mathrm{F}$ to the lease's disposal well. The water was injected into the Repetto Formation at about 4,000-4,500 feet deep. Similarly, the "Hellman Estate" lease sent its production (about 60 gal/minute at $100^{\circ} \mathrm{F}$ ) to a central facility where about $47 \mathrm{gal} / \mathrm{minute}$ of water was separated and piped to a separate injection facility. This water was treated and disposed of via a small water-flood project and a disposal project both at depths between 4,000 and 6,000 feet. The central facility at Getty's "Bryant" lease processed about 34 gal/minute, from which an average of $28 \mathrm{gal} / \mathrm{minute}$ of water at approximately ambient air temperature was sent to the lease's two disposal wells.

The closest tank facility at the Sunset Beach 0 il field is over a kilometer from the southern boundary of the weapons station. Total waste water produced at the field's 5 wells in 1983 was only about $12 \mathrm{gal} / \mathrm{minute}, 10$ of which were from Beach Supply Company's Sunset Heights Community No. 1 well. All water was disposed of via sewer systems.

Total thermal energy (Btu/hour) was estimated for $0 i 1$ and water processed at each lease based on equation 1 discussed earlier. Estimates ranged from a high of $2.35 \times 10^{6} \mathrm{Btu} /$ hour at the "Alamitos" lease to less than $0.008 \mathrm{x}$ $106 \mathrm{Btu} /$ hour at Hellman Estate's "City of Seal Beach" lease. The second highest amount of energy was at the "Hellman Estate" lease with $1.08 \times 10^{6}$ Btu/hour, about 2 times less than that at the "Alamitos" lease.

DRILLING OF WELLS TO PRODUCE THERMAL WATER

In a presentation similar to that made earlier for the Long Beach naval base, we discuss here the possibility of drilling wells at the Seal Beach Naval Weapons Station to produce thermal water.

Temperature

To attain temperatures of atmospheric boiling of water $\left(212^{\circ} \mathrm{F}\right)$ and above, especially for any production of electricity, it would be necessary to drill to a depth of at least about $6,500-7,000$ feet in the southwest part of the weapons station. Temperatures sufficient for some nonelectrical applications $\left(<212^{\circ} \mathrm{F}\right)$ could be attained at shallower depths less than about 6,500 feet. The temperature of water at the well-head, however, would be less than the rock formation's temperature because of the lag time of pumping and resuitant cooling by conduction.

At first glance, the Newport-Inglewood fault zone might be a promising structure to drill because it may contain water with higher temperatures at given depths than would be predicted by the conduction-dominated geothermal gradient of Figure 11. This "excessive" temperature results when waters 
heated at far greater depths in the earth's crust are able to ascend by convection along open fractures in the fault zone such as that intersected by the Seguro No. 1 well in Huntington Beach 0il Field. Unfortunately, except for Seguro No. 1, no oil wells or exploratory holes in the area have reportedly encountered any anomalously high-temperature water when drilled into the Newport-Inglewood fault zone.

Permeability ...

The low permeabilities in sedimentary rocks below a depth of about 6,000 feet would likely offset any advantages of higher temperatures at those depths. For an optimum combination of permeability and temperature, zones 5,000-6,000 feet deep are probably the best candidates for any proposed drilling. Here, permeabilities are over 1,000 md in some horizons and temperatures of $180^{\circ}-200^{\circ} \mathrm{F}$ are expected, high enough for some nonelectric uses. A well in these horizons might be capable of producing on the order of $150 \mathrm{gal} /$ minute (J. Richardson, personal communication, 1983). Above these depths, permeabilities improve in general, but temperatures correspondingly decline.

Recharge

Recharge of water-bearing zones by percolation of surface waters is presently effective only to depths of a few thousand feet beneath the weapons station. Below these depths, less is known of the hydrology of the sedimentary units, al though it is probable that the saline-water-bearing zones become increasingiy isolated hydrologically because of faults and impermeable shale layers. Consequentiy, if water is produced from these deep zones, they may not be sufficiently recharged to continue as reservoirs for production of thermal water. Also, subsidence may occur if large quantities of water are produced from these isolated zones. To prevent these problems, it would be necessary to inject chemically-similar waters into the zones.

Pumps, rather than natural flow, would be necessary in most cases to produce water from geothermal wells drilled on the naval base; natural flow might be sufficient for a short time but would eventually decline and then cease al together. Natural water drive is reportedly strong in parts of the Bixby, Selover, and Upper Wasem zones (J. Richardson, personal communication, 1983), but is substantially lower in the McGrath zone because of previous oil production and, more importantly, low permeability. Pumping of large quantities of thermal water from any of these zones will eventually cause the reservoir energy to decline.

Effects on Production of 017

As discussed previously, oil field operations at the weapons station are very limited; oil is produced from a very small subsurface area and thickness compared to the total size of the sedimentary section beneath the naval base. There are no major water-flood projects currently under the base; consequently, the extraction of thermal waters vertically and horizontally away from the production zones of the oil field would probably have little effect on these zones, assuming that protection against subsidence is undertaken. Currently, there is no known subsidence caused by production of oil from beneath the weapons station. 
Drilling and Operation of Wells

Plate 2 shows the approximate areas of the weapons station where the U.S. Government has reserved subsurface mineral rights. The mineral rights of the remaining area of the naval base are reserved by Hellman Estate, RCU Operator, and LOS ATamitos Land Company. Whether these subsurface rights include geothermal energy beneath the weapons station is not known.

At least one production well and one injection well would be necessary to produce and dispose of thermal waters. An injection well is needed not only because of recharge and possible subsidence but because governmental regulations state that large quantities of saline waste waters cannot be disposed of at the ground surface. Each well would probably cost at least a million dollars if drilled to depths of 5,000-6,000 feet. The poor chemical quality of the water would require special treatment to prevent scaling and corrosion in the wells; currently, oil wells at the "Alamitos" lease must be treated to prevent formation of calcium sarbonate scale.

Completion, pumping, and maintenance of the wells, in addition to a program of monitoring the performance of both wells and reservoir, will add expenses. The monitoring is essential to sustain optimum production and life of the reservoir.

The drilling of geothermal wells on the weapons station might be bypassed if an existing oil well operated by Hellinan Estate or RCU Operator were converted to production of thermal water, either by deepening of the well or alteration of its perforated intervals. A disadvantage is that the oil leases have relatively few wells on or very near the naval base, and none of the wells may currently be in a state at which abandonment as oil wells in imminent.

\section{EXTRACTION OF HEAT FROM OILFIELD OPERATIONS}

Compared to drilling geothermal wells on the weapons station, the use of existing oilfield operations in the Seal Beach 0il Field as a source of geothermal energy is less complicated and much less costly, al though very limited in size. Operations at the Sunset Beach 011 Field are too small and too distant to be sources for the weapons station, therefore, they will not be discussed in this section.

Wells Versus Central Facilities as Sources of Heat

In 1983, fluids from production wells at the "Alamitos" lease had the highest temperatures (up to $163^{\circ}$.F) in oil field operations on or adjacent to the naval base. On the other hand, the maximum rate of production from any well was less than $10 \mathrm{gal} / \mathrm{minute.} \mathrm{The} \mathrm{few} \mathrm{injection} \mathrm{and} \mathrm{disposal} \mathrm{wells} \mathrm{on} \mathrm{the}$ oil leases had rates of injection several times higher than this rate, but their temperatures were substantially lower, especially at the Hellman Estate and Getty leases.

The central facilities of the three: main oil leases (Alamitos, Hellman Estate, and Bryant) process relatively small volumes of fluid at low temperatures. Of the three, the "Alamitos" facility had the highest temperature and volume in 1983 and is closest to the main buildings of the 
weapons station (the nearest are less than 1 kilometer away). Facilities at the other two leases are about 1 to $11 / 2 \mathrm{kilometers}$ away and have lower temperatures and volumes.

Effects of Extraction of Heat on 0ilfield Operations

As at Wilmington $0 i 1$ Field, the possible effects of extraction of heat on chemical equilibria and efficiency of oil recovery are important here.

Scaling of calcium carbonate and corrosion by high salinity are problems in operations at the Seal Beach 0il Field. Reduction of the produced water's temperature to ambient air temperature may or may not cause additional problems with scaling, although calcium carbonate should be more soluble with decreasing temperature. Perhaps the initial temperatures are low enough that further reduction may have little or no adverse effect on the chemical balance in the field operation.

Regarding retention of heat for increased recovery of oil, the natural viscosity of the oil produced here is relatively low, especially compared to that in the Tar and Ranger zones in the Wilmington oil Field. Consequently, mobility of oil from the well through the processing system may not be significantly reduced by extraction of heat from the processing facility. Furthermore, most waste water from the oil field is injected as a means of disposal, not for recovery of more oil from the reservoir. As a result, there is no need to retain heat in the water as it is injected, unless the reduced temperature disrupts the chemical equilibrium of the zone into which the water is injected.

Transfer of Heat

Because of the poor chemical quality of the water produced from the oil leases, a heat exchanger and closed loop of secondary liquid would be necessary to transfer heat from the leases to intended uses on the naval base. The oil field operations are in undeveloped areas with sufficient space for such heat-exchange systems. The minimum length of pipe to carry the secondary liquid from the "Alamitos". lease to uses at existing facilities on the weapons station would be about a kilometer; uses closer than this are not presently possible because of the location of the wildlife refuge. Pipelines from the Hellman Estate and Getty facilities would be longer and are probably uneconomic because of the minimal amount of heat available. In any case, once the heated secondary liquid reaches its destination, its temperature could be boosted by use of other fuels.

The ownership, cost, and use of the heat in the oil field operations would have to be determined among all parties with legal rights in such a project. RCU Operator is tentatively interested in providing heat from its operations on the "Alamitos" lease for use on the naval base (Doc Crane, personal communication, 1983).

Longevity of 0ilfield Operations

Most of the oil zones in this part of the Seal Beach 0il Field are still on primary production. Field operations are expected to continue beyond the year 2000 based on economic trends (J. Richardson, personal communication, 1983). When the field is depleted of oil, economics will determine whether or not the oil field operations can be converted to the production of thermal water. 
LONG BEACH NAVAL SHIPYARD AND NAVAL STATIION

The geothermal conditions beneath the Long Beach naval base are characterized by slightly-above-average conductive heat flow from the crystalline basement high into the overlying blanket of sedimentary rocks, which have low thermal conductivity. The thickness of the sedimentary blanket ranges from about 5,900 feet beneath the nor theast part of the base to possibly 8,500 feet beneath the southwest part. The lower two-thirds of the sedimentary rocks are part of the faulted, southwest-dipping flank of the Torrance-Wilmington anticline. There are no known convective thermal anomalies associated with the flank of the anticline.

The overall geothermal gradient in the sedimentary section is about $3.1^{\circ} \mathrm{F} / 100$ feet $\left(5.6^{\circ} \mathrm{C} / 100\right.$ meters $)$, which is almost twice the earth's average. Extensive water-flooding associated with production of $0 i 1$ in the Tar, Ranger, and Upper Terminal zones has, however, probably lessened the gradient somewhat within these zones. The relatively high natural gradient in the deeper zones is probably caused by the shallowness of the highly conductive basement.

Temperatures of about $212^{\circ} \mathrm{F}$ are exper:ted at depths of approximately 5,300 feet in this area. Beneath the nor theast part of the naval base, temperatures at the basement-sediment contact may be about $230^{\circ} \mathrm{F}$. Beneath the southwest part, where the contact is deepest, temperatures may be about $325^{\circ} \mathrm{F}$.

Recharge of fresh water to the ground water system beneath the naval base is effective only to depths of a few thousand feet. Below these depths, the ground water is saline and is known to range up to about 34,000 ppm total dissolved solids with ions of sodium and chloride dominant. Permeabilities of the sedimentary rocks generally decrease with depth and range from moderate to high in fresh-water aquifers and low to moderate in the saline-water zones. The Schist Conglomerate zone locally may have moderate permeability, and wells drilled into these more-permeable sections may be capable of producing on the order of $100 \mathrm{gal} / \mathrm{minute}$ of water with temperatures of at least $230^{\circ} \mathrm{F}$. The basement is impermeable except where open fractures may contain minor quantities of thermal water. A disadvantage of the saline-water zones is that, with depth, the zones likely become increasingly isolated hydrologically because of faulting, wedging out of sandstone layers, and the abundance of impermeable shale layers. Such isolation could create a non- or weakly-renewable source of water unless the system is artificially recharged by injection.

Drilling of geothermal wells on the naval base is likely not economical at this time for several reasons. Most importantly, the expenses of drilling and operating wells (both production and injection welis would be necessary) would probably be much greater than the economic value of the heat in the produced water. To reach temperatures for minimal production of electricity, for example, wells would need to be more than 6,000 feet deep. At these depths, permeabilities may be too low and pumping costs too high to produce the quantities of water to make a well economic. The poor chemical quality of the water adds cost to maintenance and requires that the water be disposed of via subsurface injection. Also, prevention of subsidence is necessary if wells are drilled to remove large amounts of water from beneath the naval base, not to mention possible adverse effects on the present production of oil. Regarding the production of $0 i 1$, however, the conversion of a few oil wells at 
the naval base to geothermal wells may be worthy of brief study as an alternative to drilling new wells.

Among oilfield operations on and adjacent to the naval base, a few of the central processing facilities of Long Beach 0il Development Company and Champl in Petroleum Company may be useful sources of thermal energy for the base, mainly because of the large quantities of water they process. If sufficient heat were extracted to reduce the water temperature at these facilities to $64^{\circ} \mathrm{F}$, the water would contain about $10^{7}-10^{8} \mathrm{Btu} / \mathrm{hour}$ of thermal energy. The "Island" injection plant has the best promise as a source of heat because of its volume $\left(5,200\right.$ gal/minute at $\left.112^{\circ} \mathrm{F}\right)$ and close location (about 200 meters north of the naval base). The "Pjer $E$ " injection plant is situated on the base, but contains about 5 times less energy than the "I sland" plant. The "Island" collection plant contains about 1.5 times the energy of the "Island" injection plant, but is 3 times farther away from the base. The "XY" facility of LBOD is poorly situated because it is across a shipping channel. Although temperatures as high as $161^{\circ} \mathrm{F}$ were measured on some of them, extraction of heat at individual wel1-heads is not recommended mainly because of their. low rates of production. An exception may be a well such as W-289, which produces about 100 gal/minute of $118^{\circ} \mathrm{F}$-fluid.

The first step in the initiation of a project to use the central facilities as sources of thermal energy for use on the naval base is to determine the ownership of the rights to the heat in the water and then determine if the owner and the operator of the central facility (if different from the owner) are agreeable to the concept of such a project. If they are agreeable, an engineering study must be made to determine the use and cost of energy at the naval base and whether the extraction and transport of heat from a central facility will reduce those costs. Among many items to consider in the engineering study are the following: The project will require a

heat-exchanger system because of the poor chemical quality of the water. Whether the extraction of heat from a central facility will disrupt the chemical equilibria in the oil field operation is not known but may be minor. Regarding efficiency of 011 recovery, both LBOD and Champl in atteimt to retain as much thermal energy as possible in their entire operations mainly because of the low gravity of the oil produced from the Tar and Ranger zones. Consequently, they have been reluctant to seriously support the idea of extraction of heat from their central facilities for outside applications. Both companies expect oil production at and near the naval base to continue into the 21st Century. Perhaps in that century, when the oil is depleted, it will be economical to convert some of the oil field operations to the production of thermal water for applications at the naval base.

SEAL BEACH NAVAL WEAPONS STATION

Like the Long Beach naval base, the Seal Beach Naval Weapons Station overlies a crystalline basement insulated by a large thickness of sedimentary rocks with low overall thermal conductivity. Depth to basement is estimated to range from about 12,000 feet beneath the southwest part of the base to 20,000-22,000 feet beneath the north part. Heating of the sedimentary rocks is by conductive heat-flow from the basement; there are no known convective thermal anomalies beneath the naval base, inciuding the Newport-Inglewood fault zone. 
The geothermal gradient in the sedimentary rocks beneath the southwest part of the weapons station is estimated at about $2.2^{\circ} \mathrm{F} / 100$ feet $\left(4.0^{\circ} \mathrm{C} / 100\right.$ meters), which is a little above the earth's average. It is lower than that at the Long Beach naval base most likely because of the much greater depth to basement here. Where applicable, a projection of the gradient indicates a temperature of $212^{\circ} \mathrm{F}$ at about 6,600-6,700 feet deep. At the basementsedimentary rock contact, which is at dep ths of about 12,000 feet and greater, it indicates temperatures in excess of $300^{\circ} \mathrm{F}$.

Fresh water is present to depths of approximately 1,700 feet beneath the southwest part of the weapons station and increases to over 3,000 feet beneath the north part. These depths also are the approximate lower limits of fresh-water recharge. Permeabilities of the fresh-water aquifers range from moderate to high and, in general, decrease with depth. Sedimentary rocks bel ow the fresh-water zones contain saline waters with total dissolved solids known to range up to about $31,000 \mathrm{ppm}$; sodium and chloride are the dominant ions. Permeabilities in the saline-water-bearing sandstones are moderate at depths of about $4,000-6,000$ feet but are very low at depths below about 8,000 feet because of compaction from deep burial. Wells drilled into the most permeable zones at about 5,000-6,000 feet depth may be capable of producing on the order of $150 \mathrm{gal} / \mathrm{minute}$ of water at about $180^{\circ}-190^{\circ} \mathrm{F}$. As at the Long Beach naval base, hydrologic isolation of saline-water-bearing zones is expected to increase with depth beneath the weapons station, especially within the Newport-Inglewood fault zone. This isolation is caused by faults, wedging out of sandstone layers, and impermeable shale layers and will result in the zones' inability to sustain production of large volumes of water because of the absence or paucity of natural recharge.

Regarding the location of promising geologic structures that might produce high-temperature waters, the gravity survey conducted by the Division of Mines and Geology corroborated the presence of some of the domes and anticlines along the Newport-Inglewood fault zone beneath and adjacent to the naval base. The survey also suggested that these domes and anticlines apparently align on top of a larger regional anticline associated with the fault zone, which is represented by a northwest-trending positive gravity anomaly. Otherwise, the survey did not reveal any strong anomalies that could represent any previously unknown large faults or structural highs (shallow basement) that might contain water with temperatures higher than those indicated by the estimated geothermal gradient.

For the generation of electricity, temperatures and permeabil ities beneath the weapons station are not within current economic drilling limits. The optimum combination of temperature and permeability here may be about 5,000-6,000 feet, but this is probably too deep to justify the expenses of drilling and operating geothermal wells solely to produce thermal water for nonelectrical applications. Below these depths, permeabilities are probably too low to sustain large rates of production necessary to make such applications worthwhile. The fresh-water aquifers have high permeabilities at shallow depths ( $<1500$ feet), but the temperatures are too low. From a different perspective, conversion of oil wells on the leases of either RCU Operator or Hellman Estate may warrant study as an alternative to drilling new geothermal wells.

Regarding oil field operations as sources of thermal energy for the weapons station, the central facility at RCU Operator's "Alamitos" lease has the highest temperatures and volumes of any operation. The maximum available 
thermal energy of about $2.35 \times 10^{6} \mathrm{Btu} /$ hour $\left(81 \mathrm{gal} / \mathrm{minute}\right.$ of $122^{\circ} \mathrm{F}$-fluid) at this facility is somewhat small but may be a useful source of thermal energy for the naval base. The facilities at the leases of Hellman Estate and Getty are too distant and/or of insufficient thermal energy to be sources of heat for the base. The same is true of operations at the Sunset Beach $0 i 1$ Field. Despite temperatures as high as $163^{\circ} \mathrm{F}$, extraction of heat at individual well-heads is not recommended because individual oil wells at all leases produce too little fluid to be useful sources of heat.

During this study, RCU Operator stated interest in a project that would extract heat from the central facility at its "Alamitos" lease and transport it to uses on the weapons station. The ownership of this heat must be determined; however. Then an engineering study must be made to determine if the quantity of heat in the "Alamitos" facility is sufficient to justify construction of a system to extract and transport the heat. The loss of heat is not expected to harm oil field operations mainly because there is no secondary recovery project underway there that would benefit from retention of heat in the water as it is injected; because produced water is injected as a means of disposing of it, there is no economic reason to retain heat in the water. A heat exchanger will be required, however, because of the poor chemical quality of the water. Recovery of oil at the lease will likely continue past the year 2000. 


\section{SELECTED REFERENCES}

Allen, D.R., and Hazenbush, G.C., 1957, Sunset Beach 0il Field: California Division of $0 i 1$ and Gas, 43rd Annual Report of the State $0 i 1$ and Gas Supervisor.

Andreason, G.E., Pitkin, J.A., and Petrafeso, F.A., 1964, Aeromagnetic map of the Long Beach-Santa Ana area, Los Angeles and Orange Counties, California: U.S. Geological Survey Geophysical Investigations, Map GP-464, scale 1:48,000.

Barbat, W.F., 1958, The Los Angeles basin area, California, in L.G. Weeks, editor, Habitat of 0il: American Association of Petroleum Geologists, p. 62-77.

Barnes, R.M., and Bowes, G.H., 1930, Seal Beach 0il Field: California Division of 011 and Gas, 16 th Annual Report of the State $0 i 1$ and Gas Supervisor, no. 2, p. 9-31.

Beyer, L.A., and Biehler, S., 1982, Bouguer gravity map of California, Long Beach sheet: California Division of Mines and Geology, scale 1:250,000.

Bowes, G.H., 1943, Seal Beach 0il Field: California Division of Mines, Bulletin 118, p. 325-328.

Cal ifornia Department of Water Resources, 1961, Ground water geology, Appendix A of Planned utilization of the ground water basins of the coastal plain of Los Angeles County: California Department of Water Resources Bulletin $104,181 \mathrm{p}$.

Cal ifornia Department of Water Resources, 1967, Progress report on ground water geology of the coastal plain of Orange County: Unpublished office report, $138 \mathrm{p}$.

California Department of Water Resources, 1968, Sea-water intrusion: Bolsa-Sunset area, Orange County: Bulletin 63-2, 167 p.

California Department of Water Resources, 1980, Microfiche of Water Quality Data: Unpublished.

California Division of $0 i 1$ and Gas, 1974, California oil and gas fields-south, central coastal and offshore California: Volume 2.

California Division of $0 i 1$ and Gas, 1983,68 th annual report of the state oil and gas supervisor: Publication, No. PRO6, $145 \mathrm{p}$.

California Division of. Water Resources, 1.954, Survey of oil industry waters in Orange County: Water Quality Investigations Project No. 52-8-1, Report to Santa Ana Regional Water Pollution Control Board No. 8, 74 p. and appendices.

Chapman, R.H., 1966, The California Division of Mines and Geology gravity base station network: California Division of Mines and Geology, Special Report $90,49 \mathrm{p}$. 
Copp, W.W., and Bowes, G.H., 1927, Seal Beach Oil Field: California Division of Mines and Mining, 13 th Annual Report of the State $0 i 1$ and Gas Supervisor, no. 3, p. 5-16.

Crown, W.J., 1941, Wilmington 0il Field: California Division of $0 i 1$ and Gas, 26 th Annual Report of the State 011 and Gas Supervisor, p. 5-11.

Higgins, C.T., 1980, Geothermal resources of California: California Division of Mines and Geology, Geologic Data Map Series, Map no. 4, scale 1:750.000.

Higgins, C.T., 1981, Reconnaissance of geothermal resources of Los Angeles County, California: California Division of Mines and Geology, Open-File Report 82-3 SAC, $280 \mathrm{p}$.

Ingram W.L., 1966, North Block-East Extension of Seal Beach 0il Field: California Division of $0 i 1$ and Gas, 52nd Annual Report of the State 0il and Gas Supervisor, p. 63-68.

Keene, A.G., 1974, Supplemental report on geothermal resources within Los Angeles County: Engineering Geology Section of the Department of County Engineer, Los Angeles County, 4 p.

Kunze, J.F., Bowen, R.G., Foit, K., Goldman, D., and Zais, E., 1979, Reservoir development and management: Direct Utilization of Geothermal Energy: A Technical Handbook, Geothermal Resources Council, Special Report 7, p. 3-1 to 3-36.

Mayuga, M:N., 1970, Geology and development of California's giant -Wilmington 0il Field: American Association of Petroleum Geologists, Geology of giant petroleum fields, Memoir 14, p. 158-184.

Moreland, J.A., and Singer, J.A., 1969, A study of deep aquifers underlying coastal Orange County, California: U.S. Geological Survey, Open-File Report, 27 p.

Murray-Aaron, E.R., and Pfeil, A.W., 1948, Recent developments in the Wilmington 0il Field: California Division of 0 il and Gas, 34th Annual Report of the State $0 i 1$ and Gas Supervisor, p. 5-13.

Patton, C.C., 1977, 0ilfield water systems: Campbell Petroleum Series, Norman, Oklahoma, 252 p.

Plouff, D., 1977, Preliminary documentation for FORTRAN program to compute gravity terrain corrections based on topography digitized on a geographic grid: U.S. Geological Survey Open-File Report 77-535, 45 p.

Poland, J.F., 1959, Hydrology of the Long Beach-Santa Ana area, California: U.S. Geological Survey Water-Supply Paper 1471, $257 \mathrm{p}$.

Poland, J.F., Garrett, A.A., and Sinnott, A., 1959, Geology, hydrology, and chemical character of ground waters in the Torrance-Santa Monica area, California: U.S. Geological Survey Water-Supply Paper 1461, 425 p. 
Poland, J.F., Piper, A.M., and others, 1956, Ground-water geology of the coastal zone, Long Beach-Santa Ana area, California: U.S. Geological Survey Water-Supply Paper 1109, 162 p.

Ponce, D.A., 1982, Principal facts, accuracies, sources, and base station descriptions for 701 gravity stations and 1,922 offshore gridded values on the Long Beach $1^{\circ} \times 2^{2}$ quadrangle, California: National Technical Information Service Report NTIS PB83-237-370, NTIS, Springfield, Virginia $22161,51 \mathrm{p}$.

Robinson, B.A., 1974, Preliminary investigation of the geothermal resources within Los Angeles County: Engineering Geology Section of the Department of County Engineer, Los Angeles County, 4 p.

Saltzman, D., 1978, Report on reassessment of feasible geothermal resources within Los Angeles County: Engineering Geology Section of the Department of County Engineer, Los Angeles Count:y, $53 \mathrm{p}$.

Sass, J.H., Diment, W.H., Lachenbruch, A.H., Marshall, B.V., Monroe, R.J., Moses, T.H., Jr., and Urban T.C., 1976, A heat-flow contour map of the conterminous United States: U.S. Geological Survey Open-File Report $76-256,24 \mathrm{p}$.

Thomas, J.R., 1957, Extension of Wilmington 0il Field: California Division of $0 i 1$ and Gas, 43rd Annual Report of the State $0 i 1$ and Gas Supervisor, $p$. 51-57.

Yeats, R.S., 1973, Newport-Inglewood fault zone, Los Angeles Basin, California: American Association of Petroleum Geologists Bulletin, v. 57, no. 1, p. 117-135.

Yerkes, R.F., McCulloh, R.H., Schoellhamer, J.E., and Vedder, J.G., 1965, Geology of the Los Angeles basin, California - an introduction: U.S. Geological Survey Professional Paper 420-A, 57 p. 


\section{APPENDIX A}

\section{Gravity Survey at Seal Beach Naval Weapons Station}

Geophysical surveys are an important part of a complete assessment of geothermal resources. Such geophysical surveys may include measurements of the gravity and magnetic fields, and the use of various electrical and electromagnetic techniques, as well as other methods.

The gravity survey conducted by the Division of Mines and Geology consisted of detailed gravity profiles on and adjacent to the weapons station and measurements at a number of gravity stations in the surrounding area. Gravity measurements were made with LaCoste and Romberg geodetic gravity meter G129. Elevations for stations on detailed lines were obtained by surveying. Elevations for stations not on surveyed lines were obtained from bench marks, from spot elevations from U.S. Geological Survey 7-1/2 minute topographic maps, or from interpolation of 5-foot contours at known locations. A11 gravity stations were referenced to a local base station near the weapons station, which was referenced, in turn, to the Division of Mines and Geology's gravity base station 320 at the Los Angeles International Airport (Chapman, 1966, p. 24).

Five lines of gravity stations, totalling approximately 10 miles (16.5 km) in length, were obtained at a station spacing of 400 feet $(122 \mathrm{~m})$ on and adjacent to the weapons station. In addition, 84 gravity stations were established throughout the area for regional coverage. Nine of these stations were reoccupations of older gravity station sites (Ponce, 1982), but 29 of the older stations were used in the compilation without change.

A1 1 gravity data were reduced to complete Bouguer anomalies for a density of $2.67 \mathrm{~g} / \mathrm{cm}^{3}$ and referenced to the International El lipsoid of 1930 . Terrain corrections were made for each station out to a radius of $166.7 \mathrm{~km}$ (approximately 100 miles) by means of a U.S. Geological Survey computer program (Plouff, 1977).

Gravity "anomalies" are caused by lateral density changes in the subsurface rocks. Although no measurements of densities were available for the rocks in this area, it is probable that rocks of the basement complex are more dense than the overlying sediments and sedimentary rocks. Similarly, the densities of the sedimentary rocks probabiy increase, in general, with increasing depth of burial and age. Thus, local geologic structures that involve different rock units might cause local gravity anomalies. 


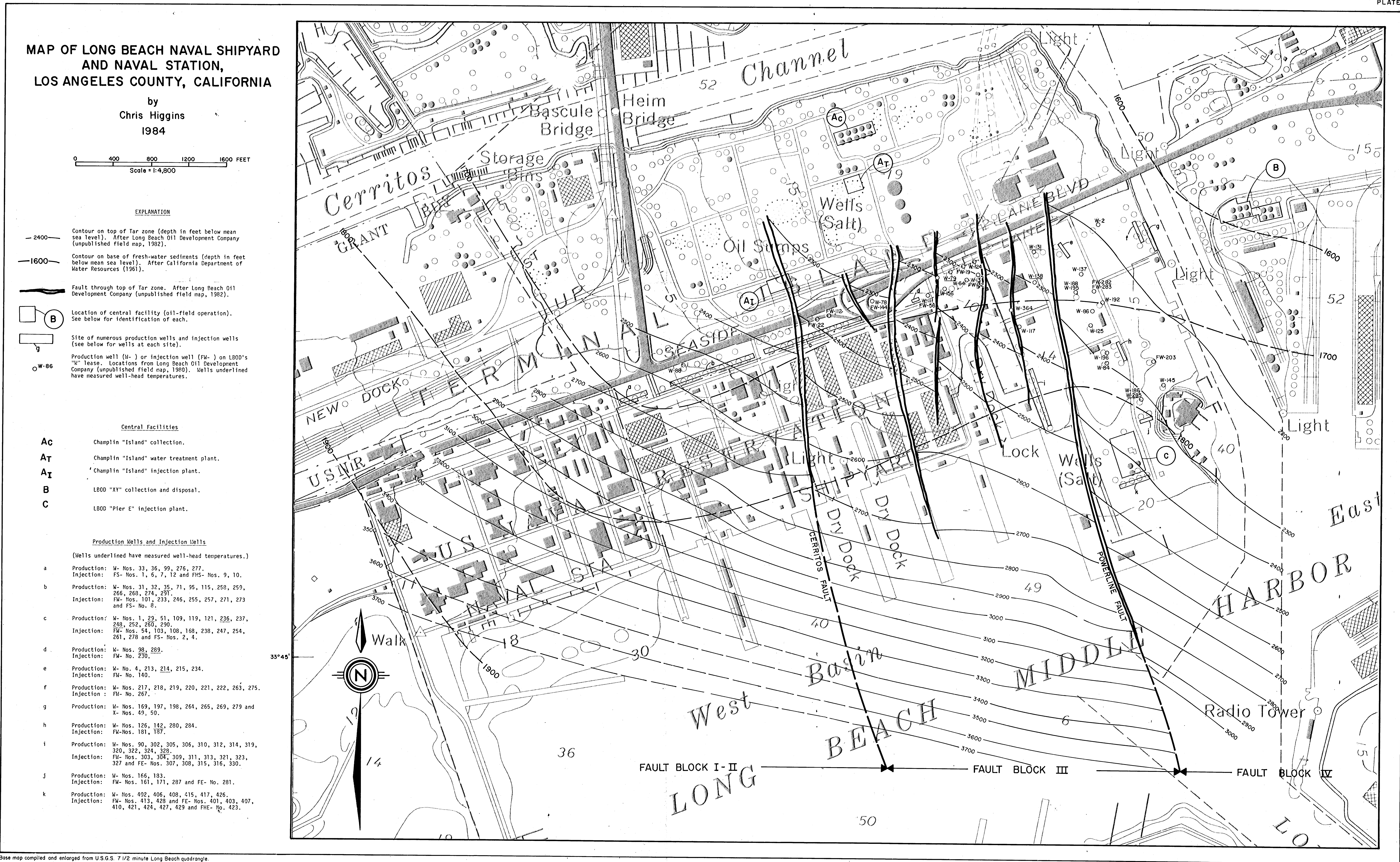


MAP OF SEAL BEACH NAVAL WEAPONS STATION ORANGE COUNTY, CALIFORNIA

Chris Higgins

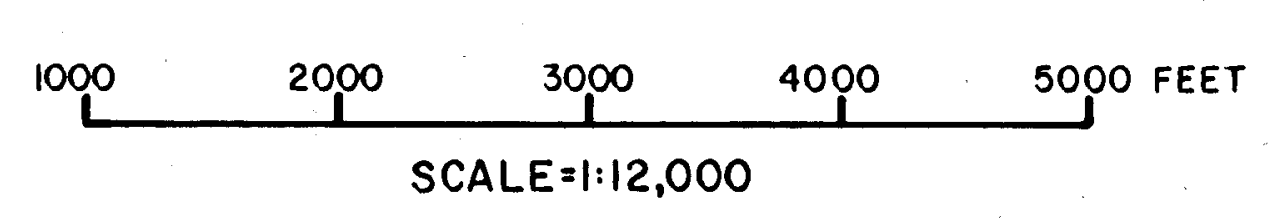

(A) Location of. central facility (oil field operation)

$W_{2} \quad$ Location of oil wells and injection/tisposal nells.

$\lambda_{10} \quad$ Location of water vell.

$\triangle 9$ Location of exploratory hole (abandoned).

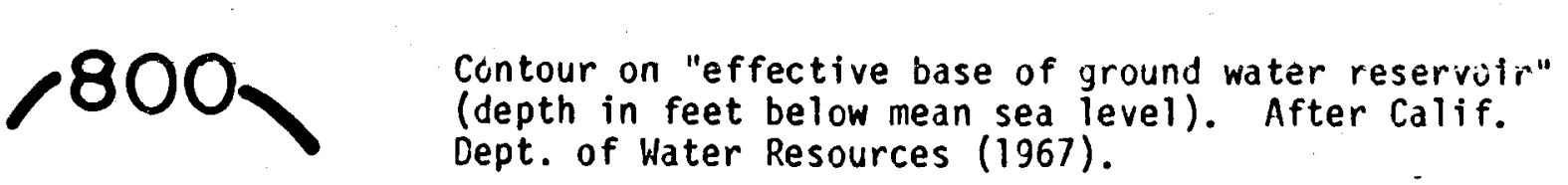

BDoundary of wespons station.

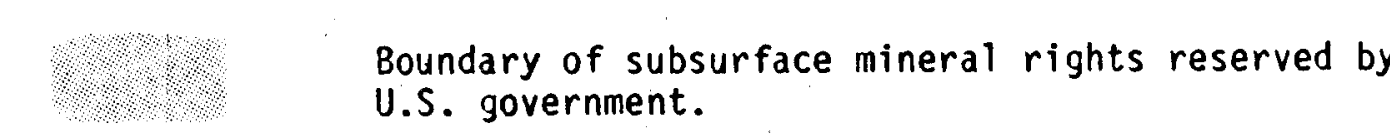

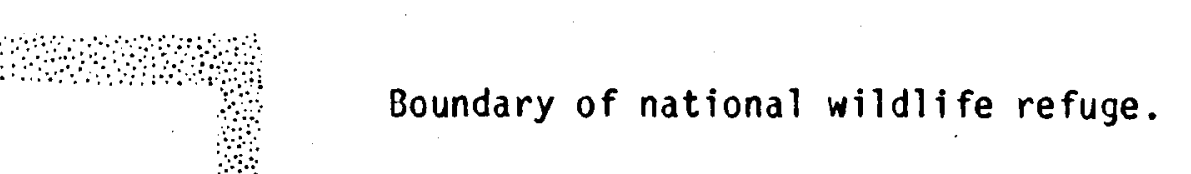

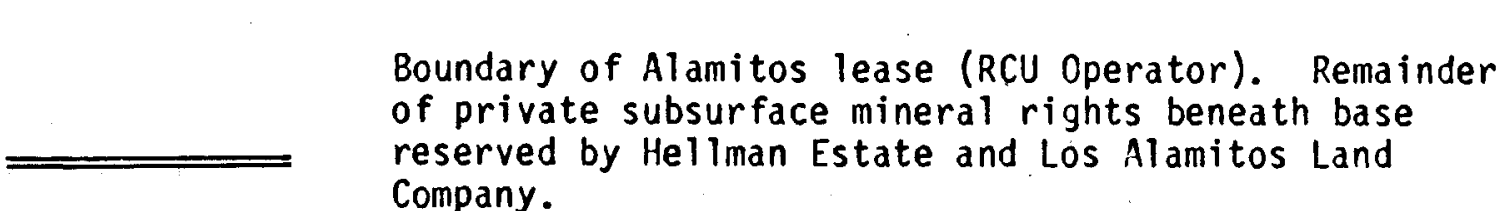

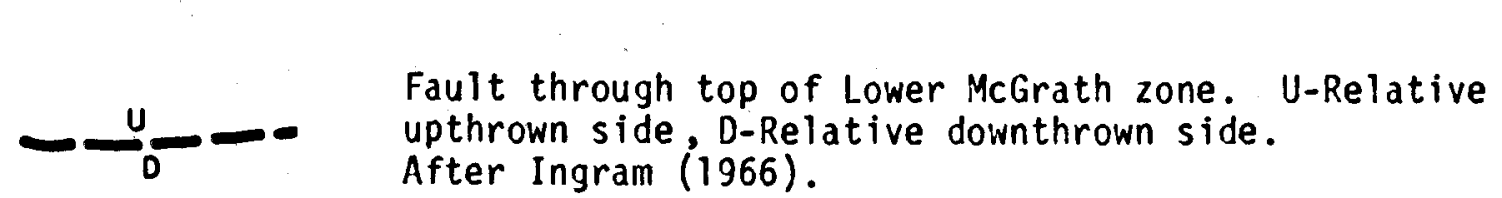

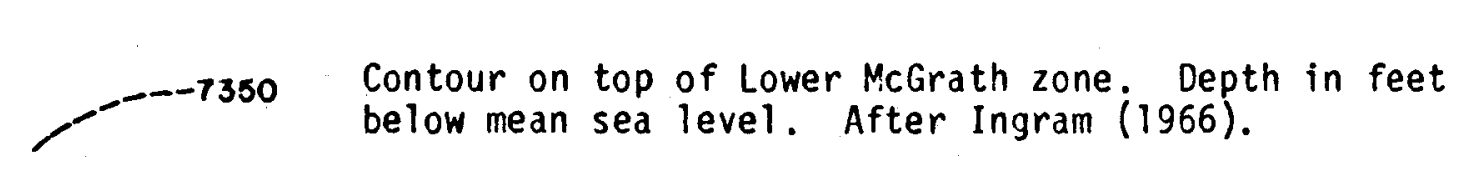
FACLITIES AND WELLS

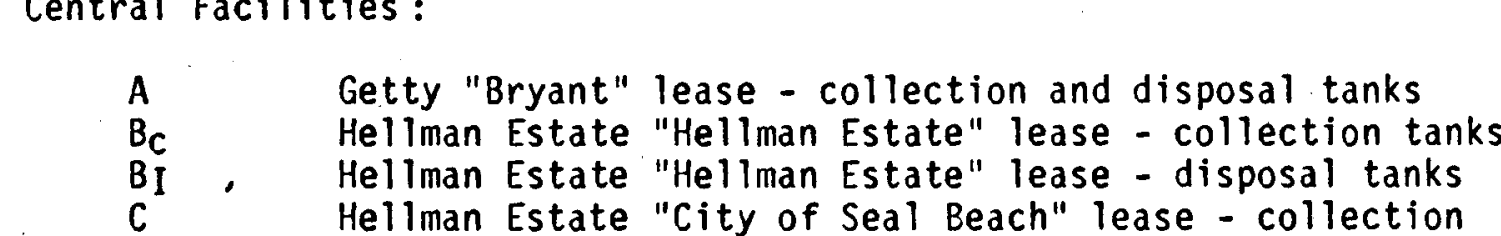

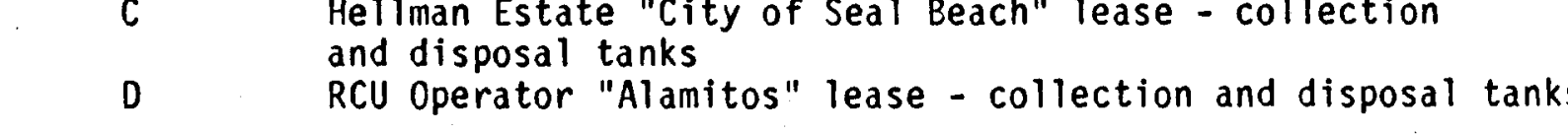

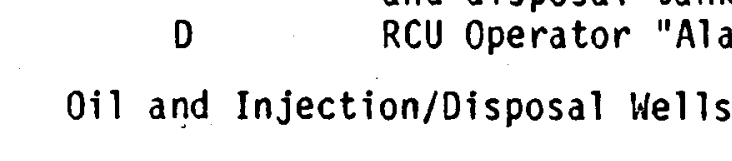

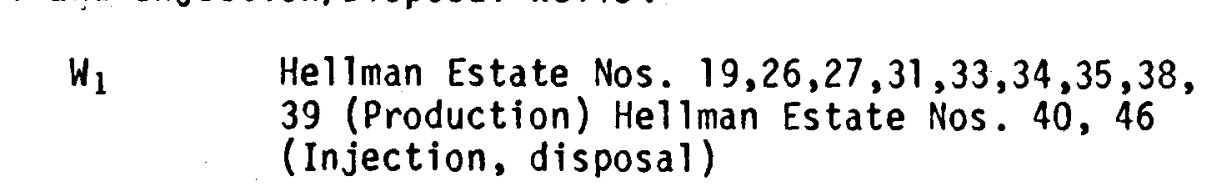

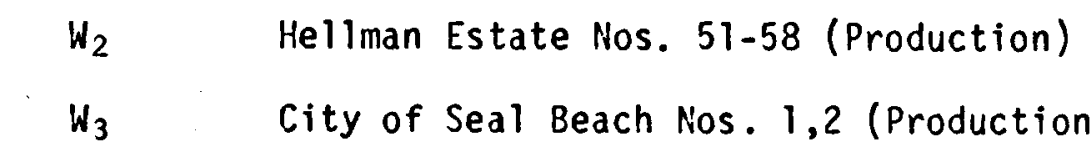

$u_{3}$
$u_{4}$
$u_{4}$

water wells:

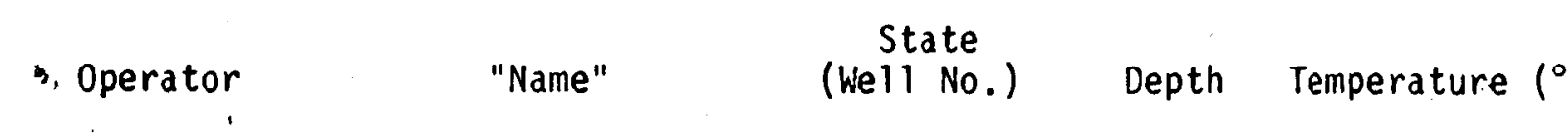

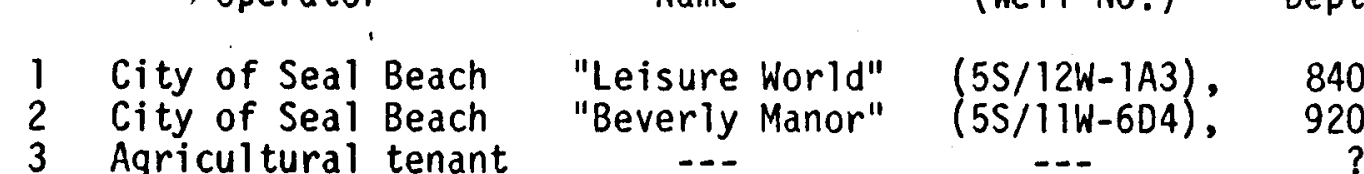

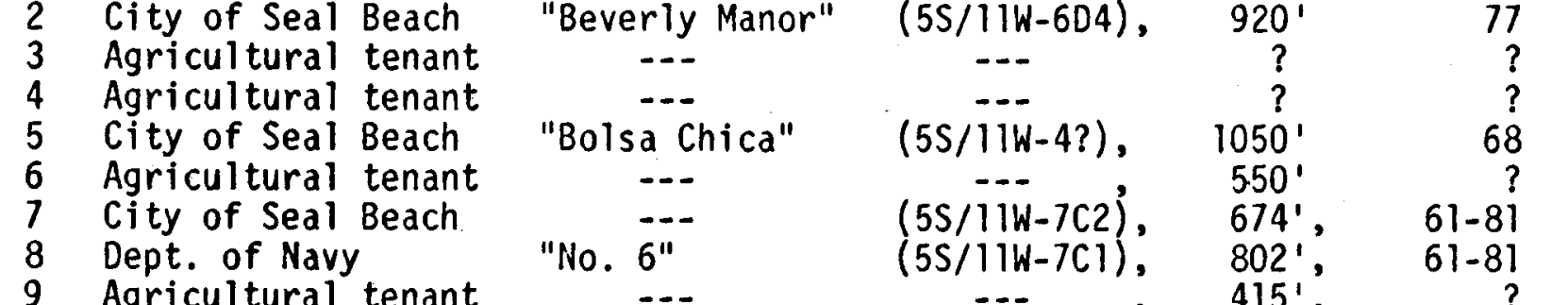

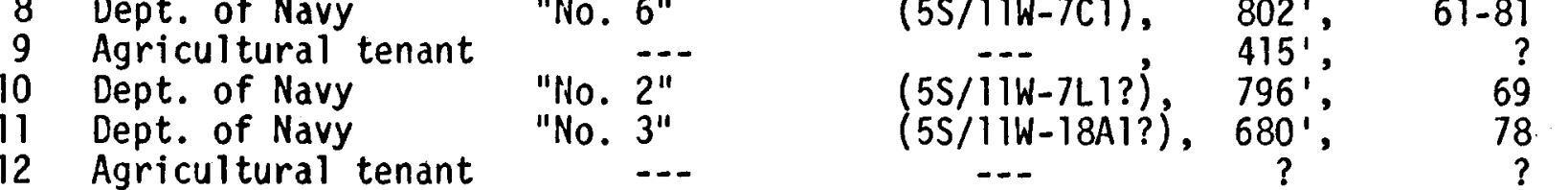

\begin{tabular}{|c|c|c|c|}
\hline $\begin{array}{l}\text { xplorazory foles: } \\
\text { llane }\end{array}$ & Year Aband. & Total oepth & BHT ( \\
\hline 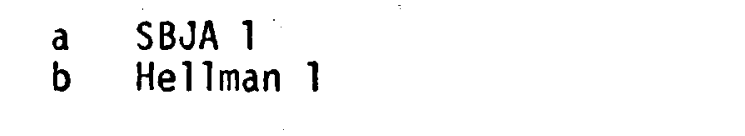 & $\begin{array}{l}1941 \\
1963\end{array}$ & 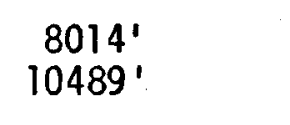 & 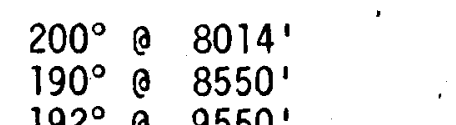 \\
\hline Hel 1 man Estates 1 & 1970 & 12455" & 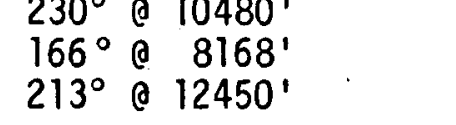 \\
\hline 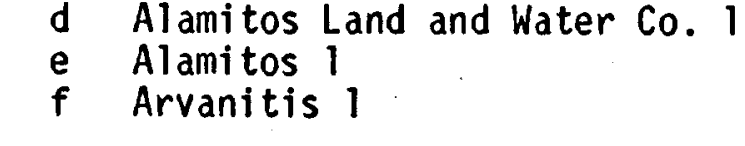 & 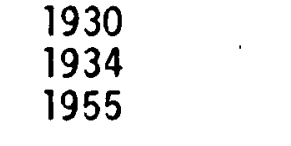 & 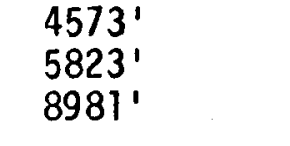 & 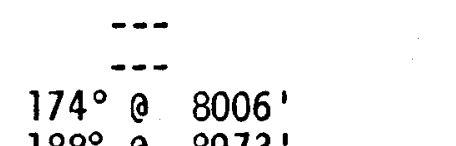 \\
\hline 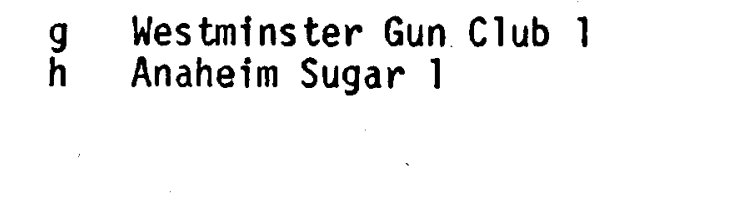 & $\begin{array}{l}1936 \\
1953\end{array}$ & $\begin{array}{l}5345 ! \\
8029 !\end{array}$ & 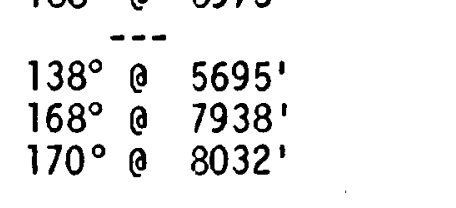 \\
\hline
\end{tabular}

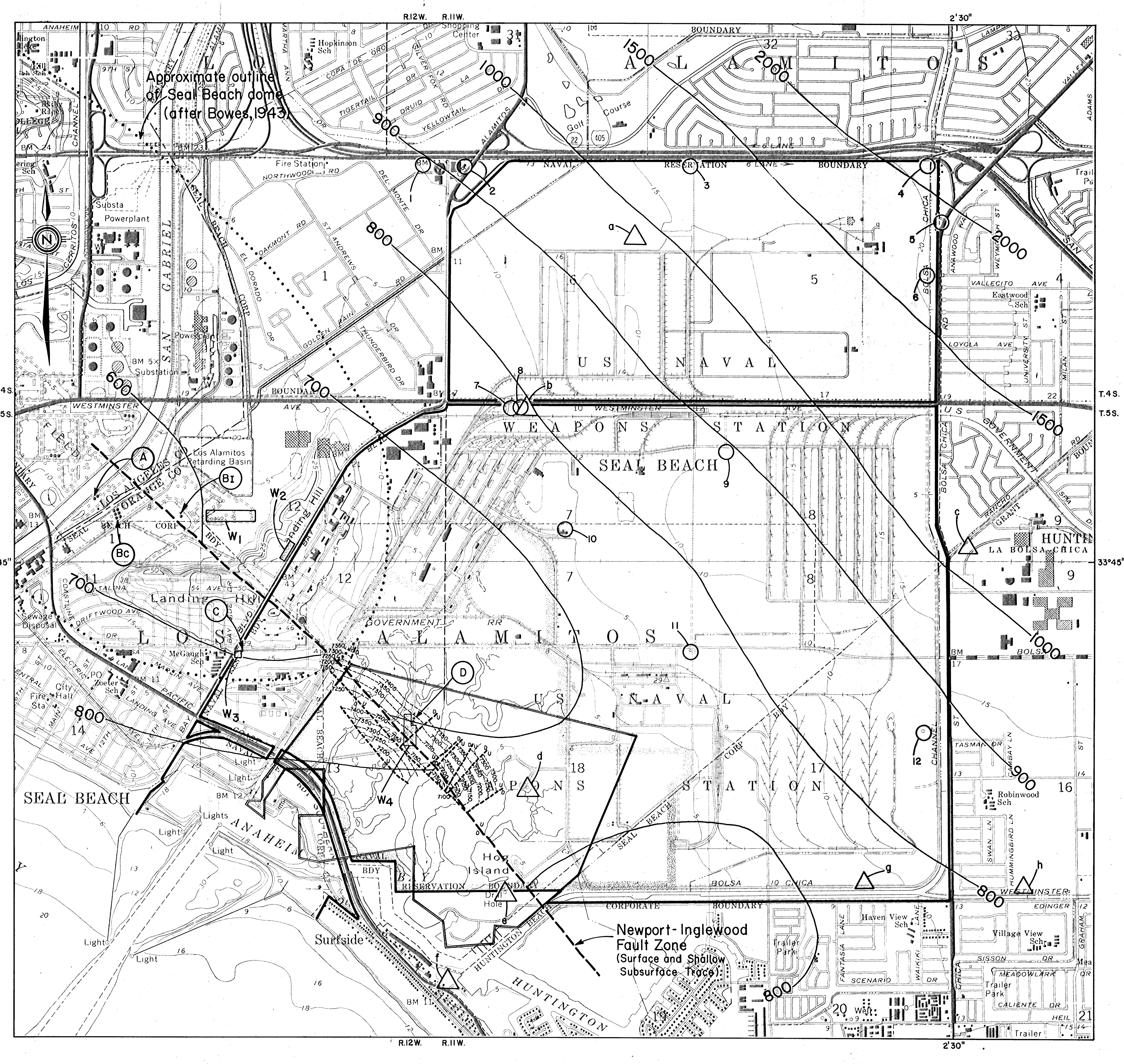

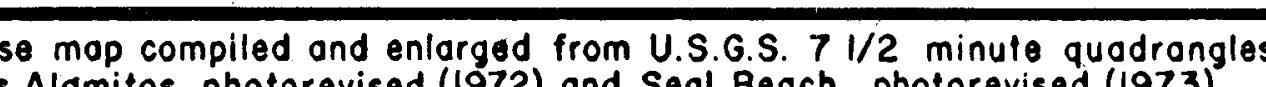




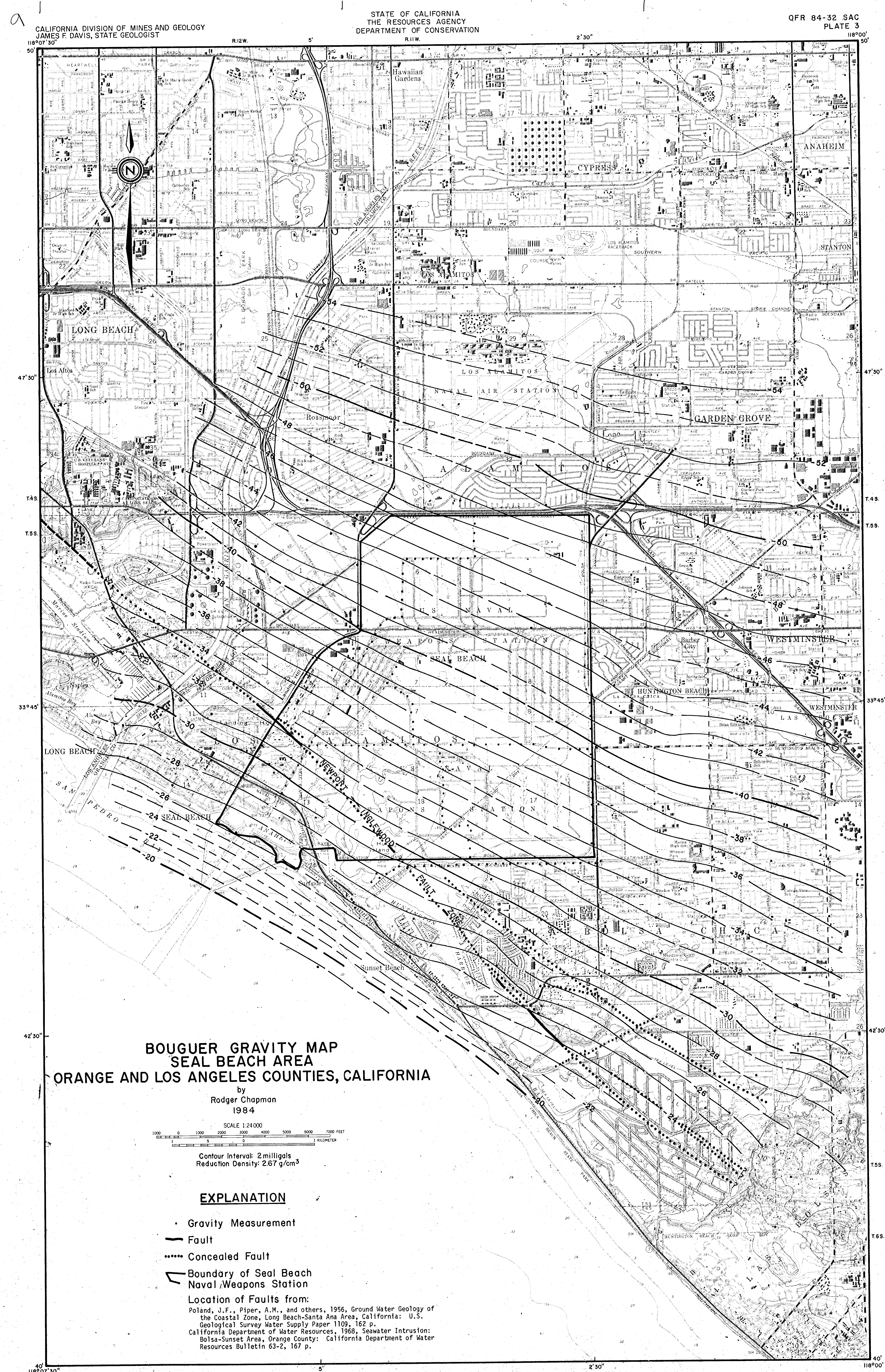




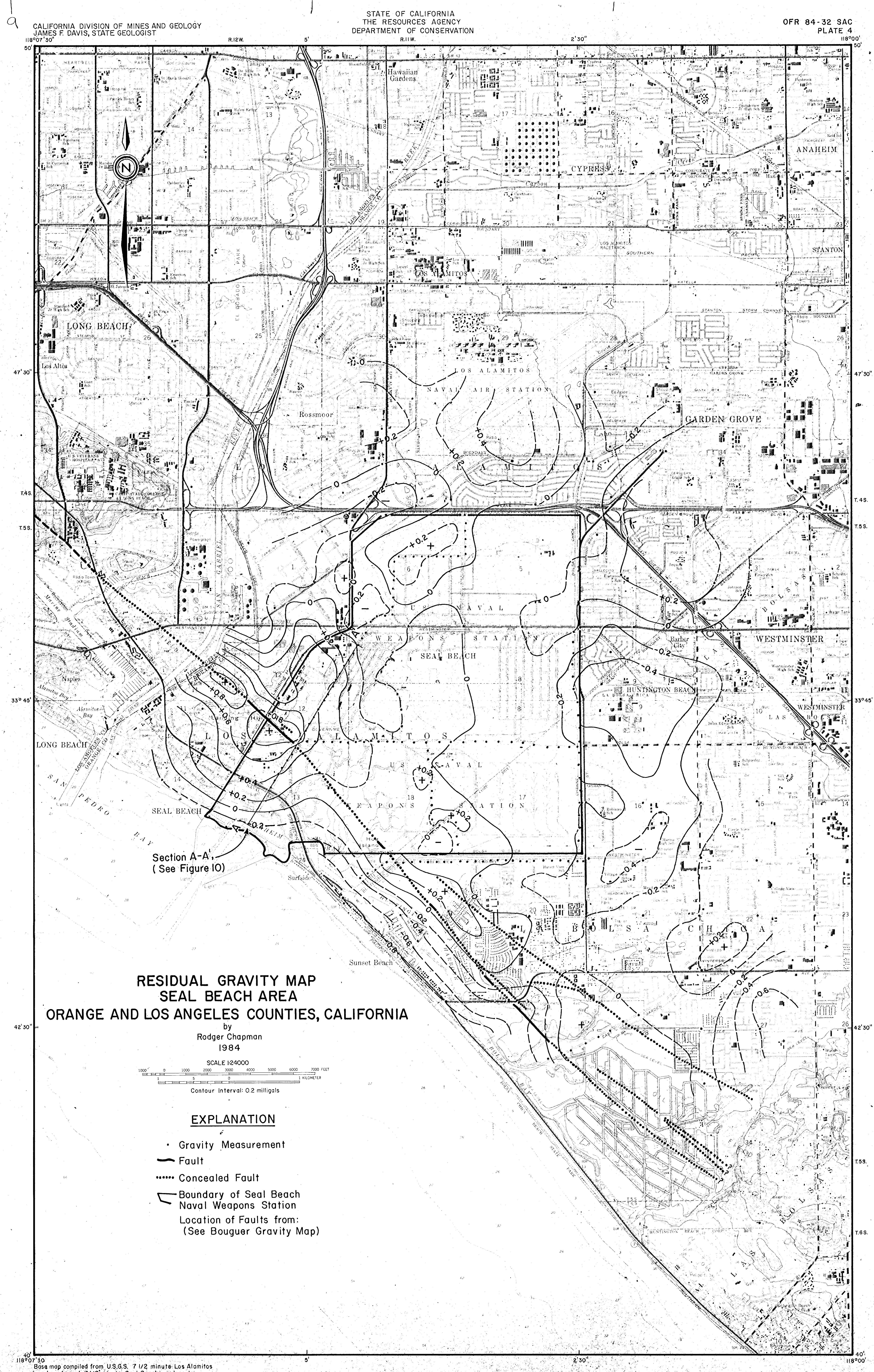

